\title{
The potential for dust detection by means of $\mu$ XRF scanning in Eifel maar lake sediments
}

\author{
Stephan Dietrich, Frank Sirocko
}

Abstract:

\begin{abstract}
Data for the annual variability of aeolian sediments is obtained from continuous and high resolution $\mu$ XRF geochemistry within maar lake sediments from the last 60 kyrs. Two sediment cores from Eifel maar lakes and dry maars (Germany) were analyzed, which covering the glacial inception of MIS-3, LGM and MIS-2, transition I as well as the Holocene. The energy dispersive XRF scanning is obtained on resin impregnated blocks of the sediment, which are the basis for the production of petrographic thin section. Thus, the measurement results can directly be compared with micro facies analysis. Quantification of the Eagle III $\mu \mathrm{XRF}$ carried out on one sediment core, using the standard free fundamental parameter method, shows that this quantification method gives suitable results by comparison with WD-XRF analysis of discrete samples. Each single maar differs in lithological composition, which is reflected in the geochemistry, too. The major processes of element deposition in lakes are therefore described, i.e. the different sedimentation and weathering processes as well as the circulation of the water body of the lake. Following on from this, it is shown that it is possible to derive an aeolian sediment signal by using principle component analysis of standardized variables. Because further knowledge about the lithology and environmental background is available (from the petrographic thin sections) it can be demonstrated that this principle component analysis approach gives reliable results for all the time slices investigated. The most prominent element for describing dust in both investigated cores $\mathrm{Ca}$, which reaches highest values ( $>5$ wt.- $\%$ ) during glacial conditions and which have major influence on the dust factor obtained by principal component analysis. In combination with grayscale values both the Ca content and the dust factor serve to, calculated by principal component analysis, the serves to record aeolian dust in laminated lake sediments. In both cores periods with major dust events could be detected by $\mu \mathrm{XRF}$ geochemistry: during MIS-3 the largest Heinrich event $\mathrm{H} 4$ and the onset of dust increase coupled to the glacial inception of the Pleni-Weichselian, further on the whole MIS-2 including LGM and YD as well as enhanced dust supply forced by human activities since the Subboreal.
\end{abstract}

\section{[Möglichkeiten der Detektion äolischen Staubs mittels $\mu$ XRF-Scannen von Maarseesedimenten aus der Eifel]}

Kurzfassung:

Mittels kontinuierlicher und hochauflösender $\mu$ XRF-Geochemieanalysen wird die Variabilität äolischer Sedimente der letzten 60.000 Jahre rekonstruiert. Dazu werden zwei Sedimentbohrkerne jeweils aus einem Maarsee und einem Trockenenmaar (Eifel, Deutschland) untersucht. Beide Kerne umfassen das letzte Glazial, einschließlich des MIS-3, des LGM und MIS-2, Transition I als auch das Holozän. Die energiedispersive RFA-Messungen der Eagle III $\mu$ XRF wird direkt an Harz imprägnierten Proben angewendet. Diese sogenannten Tränklinge bilden die Grundlage für die Herstellung von petrographischen Dünnschliffen und somit können die Messergebnisse direkt mit einer Mikrofaziesanalyse verglichen werden. Anhand eines Sedimentkerns wird gezeigt, dass eine Quantifizierung der $\mu$ XRF-Ergebnisse mittels der Fundamentalparametermethode geeignete ist. Eine Überprüfung der Ergebnisse findet dabei mit wellenlängen-dispersiven RFA-Messungen an diskreten Proben statt. Die Ergebnisse zeigen, dass sich jedes einzelne Maar in der lithologischen Zusammensetzung und damit auch geochemisch unterscheidet. Deshalb wird auf die grundlegenden Prozesse der Elementdeposition in die Seen eingegangen, die mit der Ablagerung von Sedimenten, der Variabilität der chemischen Verwitterung oder der Wasserzirkulation in Zusammenhang stehen. Mittels Hauptkomponentenanalysen standardisierter Variablen ist darüber hinaus die objektive Ableitung eines äolischen Sedimentsignals möglich. Es wird gezeigt, dass dieser Ansatz verlässliche Ergebnisse für alle untersuchten Zeitabschnitte liefert, solange für die Interpretation weitere Kenntnisse über die Lithologie und Paläoökologie zur Verfügung stehen. Das auffälligste Element zur Charakterisierung von Staub ist in beiden untersuchten Kernen Kalzium. Die höchsten Werte ( $>5$ Gew. $\%$ ) werden während vollglazialer Bedingungen erreicht. Kalzium hat einen wesentlichen Einfluss auf den Staubfaktor der Hauptkomponentenanalyse. Eine zusätzliche Kombination der Kalziumgehalte mit dem Staubfaktor der Hauptkomponentenanalyse sowie Grauwertmessungen verbessert den Nachweis äolischen Staubs in laminierten Seesedimenten zusätzlich. In beiden Kernen konnten Sedimente mit erhöhten Staubkonzentrationen geochemisch nachgewiesen werden: Während des MIS-3 sind das vor allem das größte Heinrich-Ereignis H4 sowie der Anstieg des atmosphärischen Staubgehalts während der Wiedervereisung der Inlandsgletscher. Weiterhin ist das gesamte MIS-2 einschließlich LGM und der Jüngeren Dryas von starker Staubdeposition charakterisiert. Eine erhöhte Staubkonzentration ist ebenfalls ab dem Subboreal nachgewiesen und wird als anthropogene Aktivität gedeutet.

Keywords: $\quad \quad \quad \quad \quad \quad \quad \quad$ IXFR, geochemistry, lacustrine sediment, aeolian sediment, last glacial cycle, PCA

Addresses of authors: S. Dietrich, F. Sirocko, Institute for Geosciences, University of Mainz, Becherweg 21, D-55099 Mainz, Germany. Tel.: +49 (6131) 39-23834,+49(6131)-39 22714, Fax: +49 (6131) 39-24769, E-Mail: sdietrich@uni-mainz.de, E-Mail: sirocko@uni-mainz.de.

\section{Introduction}

The investigation of long continuous aeolian sediment records, such as loess profiles or dunes are widely used to reconstruct the environmental and climate variability. Long records cover several glacial cycles and are primarily known from the large loess plains in Asia or from the Carpathian basin. Profiles with the possibility to archive annual resolution are less common. The West-Eifel Volcanic Field (WEVF), Germany, provides such records in maar lakes. Without a fluvial inlet, these lakes are perfect sediment traps for aeolian deposits (Dietrich \& Sirocko 2009, Pfahl et al. 2009). 


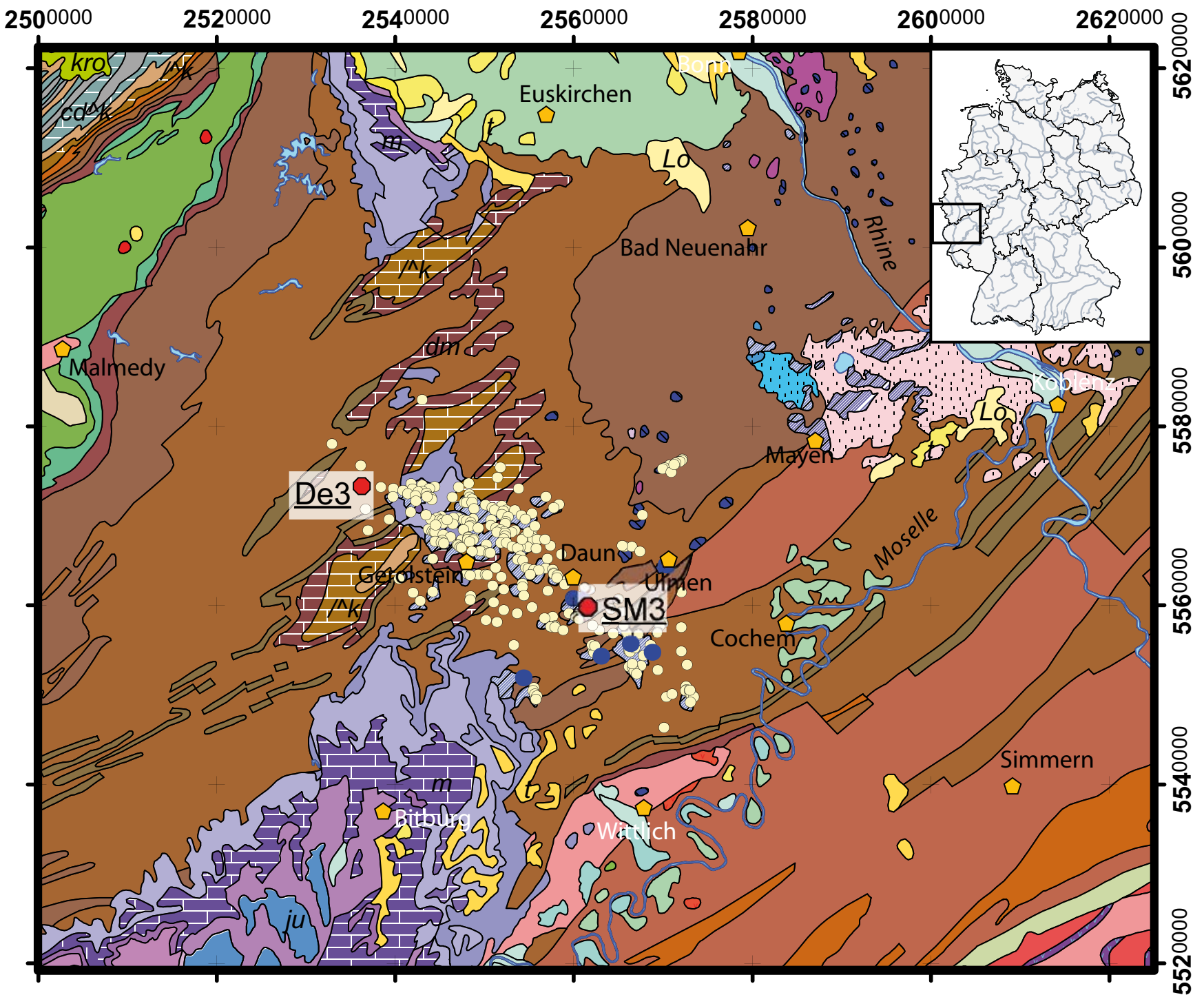

$20 \mathrm{~km}$

Legend

Lo Loess

m Muschelkalk $\triangle$ city

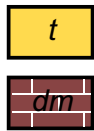

core location
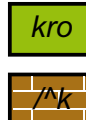

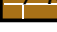

o dry maar

Upper Cretaceous

Devonian Massenkalk
Oligocene, Miocene

Middle Devonian

Fig. 1: Geological sketch map of the Eifel region and position of the cores SM3 (maar lake Schalkenmehren) and DE3 (Dehner dry maar). The map is based on the Geological Map of Germany (BGR, 1993), locations of dry maars after BÜCHEL (1994).

Abb. 1: Geologische Übersichtskarte der Eifel mit den Positionen der beiden Bohrkerne SM3 (Schalkenmehrener Maar) und DE3 (Dehner Trockenmaar). Die Karte basiert auf der Geologischen Übersichtskarte von Deutschland (1:1 000 000; BGR, 1993), Lokationen der Trockenmaare nach BÜCHEL (1994).

Furthermore, although the sediments do not show annual lamination, they are stratified by event layers due to anoxic conditions at the lake bottom (ZoLITschKA et al. 2000, Sirocко et al. 2005).

The detection of aeolian deposits in lake sediments is possible by using different approaches like micro facies analysis, measuring the minerogenous component of the bulk sediment (e.g. ZolitschKA 1998), magnetic susceptibility (e.g. YANCHEVA et al. 2007) or grain size analysis (e.g. Seelos et al. 2009, Sun et al. 2002). However, in this study a geochemical scanning approach is applied to measure aeolian deposits. High resolution geochemical analysis of lacustrine sediments offers a reliable method for in- vestigation of environmental changes in the past (Boyle 2001, Boyle 2000, Engstrom \& Wright 1984, Melles et al. 2007). The potential of X-Ray fluorescence (XRF) core scanning is based on the rapid and non-destructive acquisition of high-resolution geochemical data from lacustrine sediment cores. This facilitates new approaches to many applications in paleolimnology, including pollution detection, varve counting, and estimation of past ecosystem productivity (Francus et al. 2009). The $\mu \mathrm{XRF}$ scanner acquires bulk-sediment chemical data with sufficient accuracy for major elements (Boyle 2000). Although elemental intensities are predominantly proportional to concentration, they are also influenced by the energy level of the 
X-ray source, the count time, and the physical properties of the sediment, such as the poorly constrained measurement geometry attributable to inhomogeneity of the specimens (e.g. variable water content and grain-size distribution), and irregularities of the sample surface (WeLtJe \& TJALlingi 2008, Rothwell et al. 2006). Nevertheless, the $\mathrm{XRF}$ methodology is a widely accepted, semi-quantitative core logging method that provides records of changing element intensities expressed in "total counts", reflecting the geochemical composition of the sediments. Quantitative analysis is made more difficult by matrix effects especially for light elements such as $\mathrm{Al}$ and Si (BöNING et al. 2007). Reasons include the pore volume of interstadial water or resin or the roughness of the sediment surface. However, a recent approach to calibration of XRF core scanners for quantitative geochemical logging is applied by WeLtJe $\mho$ TJALlingiI (2008) or Kido et al. (2006). Beside the direct measurement of the core surface via core loggers the analysis of resin impregnated samples (RIS) is demonstrated in a growing number of studies. The single $10 \mathrm{~cm}$ long RIS are taken continuously down core. The pore volume of the sediment is substituted by resin during the production of the RIS. These geochemical data can be directly assigned to micro-facies data because XRF scanning has been carried out on the same impregnated sediment blocks from which thin sections can be prepared. High resolution applications are shown by different studies for example by SoRREL et al. (2007) or BrAUER et al. (2008). The latter authors have applied a geo-chemical major element micro-X-ray fluorescence scanner at $50 \mu \mathrm{m}$ resolution providing geochemical information for individual seasonal layers (5-8 data points/ varve for the Allerød; $20-30$ data points/varve for Younger Dryas) to investigate the structure and seasonal composition of varves. The first successful implementation of XRF techniques for the provenance analysis of dust is shown by NefF et al. (2008).

The objective of the work is to separate of different lithofacies, especially the aeolian input into the lake environment, by means of $\mu \mathrm{XRF}$ geochemistry and to test if $\mu \mathrm{XRF}$ data are not only a general paleoclimate signal but can be used to quantify the aeolian fraction directly to achieve dust records with annual resolution. In this study, we demonstrate how aeolian sediment within maar lake sediments might be classified by certain elements and new factors, calculated by principal component analysis (PCA).

\section{Material and Methods}

\subsection{Cores and drilling locations}

The west Eifel volcanic field (Germany) is characterized by more than 70 maar lakes and dry maar lakes (BüCHEL 1994). Two sediment cores, namely SM3 (N50 10'11.6”, E6 $\left.{ }^{\circ} 51^{\prime} 31^{\prime \prime}\right)$, from lake Schalkenmehren and DE3 (N50 17'35.5”, E6 30'22.7”, $88 \mathrm{~m}$ depth) from the Dehner dry maar (Dehner Trockenmaar) were drilled in a maar lake and a dry maar, respectively (Fig.1). On the Eastern side of lake Schalkenmehrener Maar an older dry maar is located which is connected to the lake by a marsh. Earlier fluvial input into the maar lake from this extended catchment could be proved until the Medieval Times (Straka 1975). The rim of the Dehner dry maar exhibits a pronounced roundness and shows no ancient fluvial inflow but does have an outflow to the Northwest. The core SM3 from lake Schalkenmehrener Maar was drilled using a swimming platform and a piston corer (UWITEC, Austria), DE3 was drilled with the 'Seilkernverfahren'. These two cores from the ELSA repository (Eifel Laminated Sediment Archive) cover together the main periods with major climate changes of the last 60 kyrs, including the marine isotope stages MIS-3 and MIS-2 (DE3), and transition I as well as (anthropogenic) dust events during the Holocene (SM3). In total 82 meters of sediment cores with an average sedimentation rate of $1.5 \pm 0.5 \mathrm{~mm} / \mathrm{yr}$ are analyzed. The sediments consist of detrital bearing sediment that documents weather extremes (flash floods and aeolian dust) or gyttja, containing a high amount of organic matter that documents past water conditions (temperature, nutrient content, $\mathrm{pH}$ ), which are recorded in the remains of plants and animals that lived in the lake.

\subsection{Chronology and lithology}

The stratigraphy for both cores is published in SiRocко (Ed. 2009). The core SM3 spans the Holocene and the core DE3 from the Dehner dry maar covers the time span from MIS 4 to the eruption of Lake Laach (Laacher See). In DE3 a piece of spruce could be dated by radiocarbon to $45.8+1.2-1.04$ kyrs BP at $55.56 \mathrm{~m}$ depth. Between these time marks are four stadial-interstadial sequences shown by high organic matter and therefore dark brownish color (Fig. 2). The tephra of the eruption of lake Laach (the Lacher See Tephra, LST, at 12.9 kyrs BP, van den BOGAARD 1995, WörNER \& SCHMINCKe 1984) is identified geochemically (VERES, pers. comm.) in the core, SM3 at $6.5 \mathrm{~m}$ and in DE3 at $3.4 \mathrm{~m}$ depth. Thus, the LST is used as a tie point to merge both cores to a stack, which covers the last 60 kyrs.

Core DE3 (Fig. 2) shows significant changes in environmental and climatic conditions in its sediments and oscillates between warm and organic-rich and dust-rich glacial conditions. Starting at the bottom sequence of the core, dark brown gyttja is dominant and implicates an interstadial character between 70 and $50 \mathrm{~m}$. At 43 to $41 \mathrm{~m}$ depth single but rather strong dust events had been deposited and the sediment has a brighter color until 40.50-38.90 m where dark, organic-rich matter recurs. Volcanic ashes from Eifel volcanism, mostly with unknown certain origin, cumulates between 80-78 m, and between $51-37 \mathrm{~m}$. In the core meter 36 a slide is recorded as a decimeter large fold. The following ten meters are dominated by light brown gyttja with increasing dust influence. The content of aeolian sediment reaches the highest level at $26 \mathrm{~m}$ and keeps stable until $10 \mathrm{~m}$ depth. The next eight meters dust is decreasing and at $8 \mathrm{~m}$ the first grass pollen appears (SIRоско ed. 2009). Between 7 and $2.8 \mathrm{~m}$ the content on organic matter is increasing, whereas the uppermost core sequence is characterized by debris flow/solifluction debris. The core SM3 (Fig. 3) is fine laminated in the uppermost 6 meters with an high amount of organic gyttja between 3-5 m. From $6.5 \mathrm{~m}$ down core, the sediment changes significantly to loess gyttja with a bright grey color, showing a strong influence of aeolian sediments during this period. 

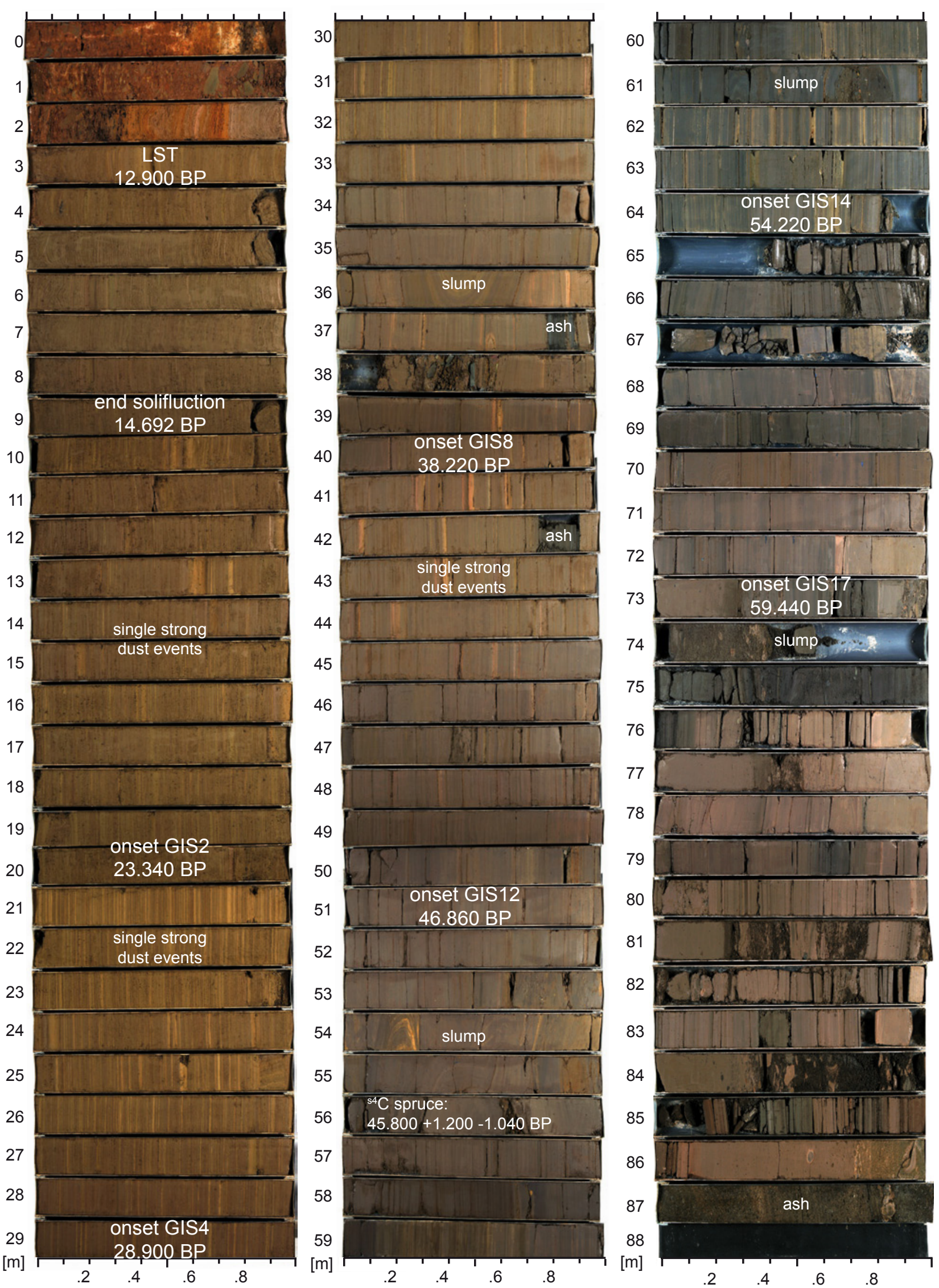

Fig. 2: Core photography and time marks (tuned to the Greenland ice core GICC05 stratigraphy (SVENSSON et al. 2008) of the core DE3. The ash of the LST is clearly visible at $3.5 \mathrm{~m}$ depth. The core sections between 35 and $10 \mathrm{~m}$ is dominated by single strong dust events (SEELOS et al. 2009; DIETRICH \& SEELOS 2010) and represent the time of the Middle Weichselian. Modified after SIROCKO (Ed. 2009).

Abb. 2: Kernfotografie und Altersmarken des Sedimentkerns DE3. Das Altersmodell basiert auf 14C-Datierungen, Tephrochronologie und ist mit der GICC05-Stratigrafie der Grönländischen Eiskerne abgestimmt (SVENSSON et al. 2008). Die Laacher-See-Tephra (LST) ist in 3,5 $m$ Tiefe deutlich erkennbar. Die Kernsequenz zwischen 35 und $10 \mathrm{~m}$ wird durch äolischen Staub dominiert (SEELOS et al. 2009; DIETRICH \& SEELOS 2010) und repräsentiert den Zeitraum der Weichsel-Vereisung. Uberarbeitet nach SIRоско (Ed. 2009). 


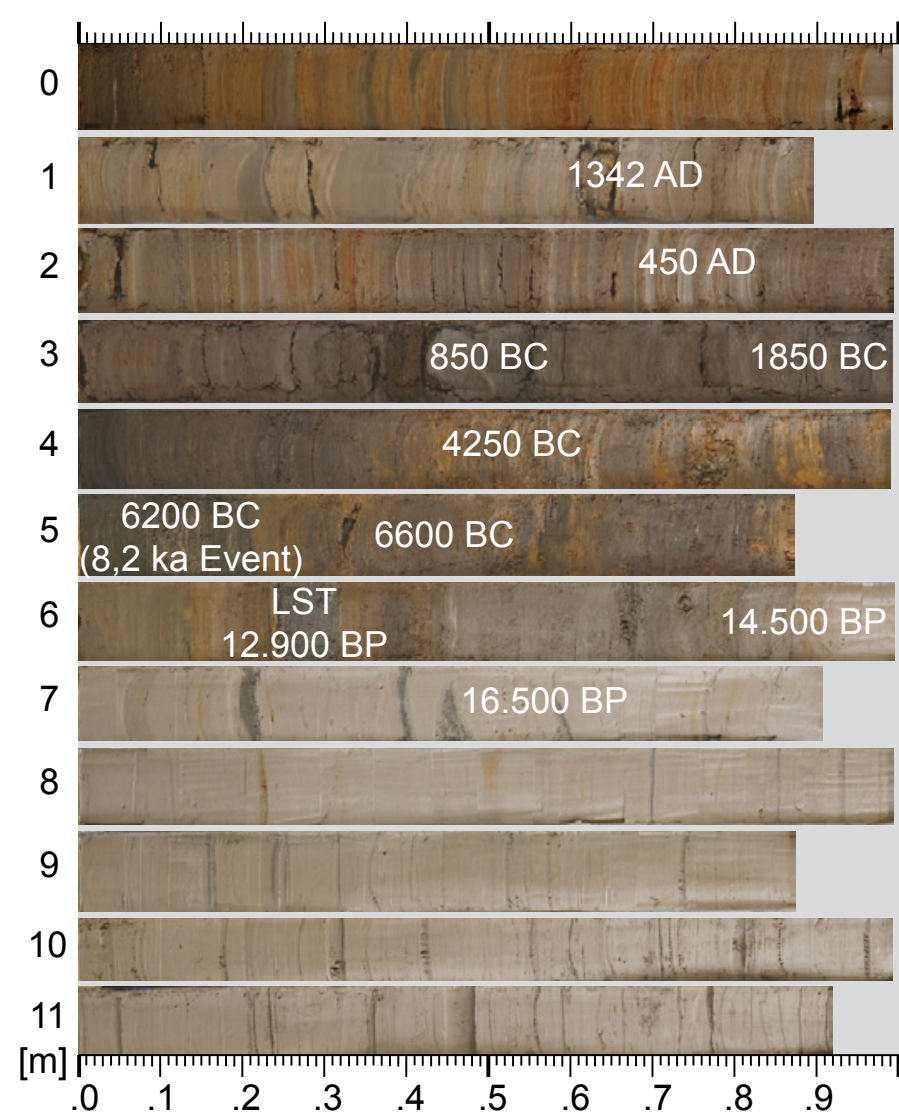

Fig. 3: Core photography and time marks of the core SM3. The ash of the LST is clearly visible (6.3 $\mathrm{m}$ depth). The deeper core sequence is dominated by bright colored aeolian sediment of the late Weichselian.

Abb. 3: Kernfotografie und Altersmarken des Sedimentkerns SM3. Die LST ist in 6,3 m Tiefe deutlich zu sehen. Die untere Kernsequenz ist durch die hellen äolischen Sedimente der späten Weichselkaltzeit gekennzeichnet.

\subsection{Evaluation of chemical data}

The three core sections were scanned for selected elements at $1 \mathrm{~mm}$ resolution using the energy dispersive X-ray fluorescence scanner Eagle III (Röntgenanalytik Meßtechnik $\mathrm{GmbH}$, Germany) of the University of Mainz (Germany). The $\mu \mathrm{XRF}$ was used to measure major elements (e.g., Mg, $\mathrm{Al}, \mathrm{Si}, \mathrm{P}, \mathrm{S}, \mathrm{K}, \mathrm{Ca}, \mathrm{Ti}, \mathrm{Mn}$, and $\mathrm{Fe}$ ) as well as trace elements ( $\mathrm{Sr}, \mathrm{Zr}, \mathrm{Cr}, \mathrm{Ni}, \mathrm{Cu}$, and $\mathrm{Zn}$ ) on $10 \mathrm{~cm}$ long resin impregnated samples. $\mathrm{Na}$ is too light for detection via the Eagle III and is therefore not included in this study. The Araldite(R) impregnated blocks are a spin-off from to the production of thin sections (DiETrich \& Sirocko 2009). Thus, the geochemical results can be directly interpreted in context with micro facies analysis. The $\mu \mathrm{XRF}$ scanner acquires bulksediment chemical data from these samples. Scans of pure Araldite indicate zero counts of the investigated element and thus do not bias the results. Although elemental intensities are dominantly proportional to concentration, they are also influenced by the energy level of the X-ray source, the count time, and the physical properties of the sediment (RöHL \& ABRAms 2000). The data were collected every $1 \mathrm{~mm}$ down-core with a $300 \mu \mathrm{m}$ spot size of the X-ray beam. The generator setting was of $30 \mathrm{kV}$ and $500 \mu \mathrm{A}$ with a sampling time of 16 seconds and a mean death time of $30 \mu \mathrm{s}$. The sample chamber is evacuated during measure- ment, thus light elements like $\mathrm{Si}$ and $\mathrm{Al}$ are also stimulated. The emitted fluorescence radiation is detected by an energy dispersive $\mathrm{Si}(\mathrm{Li})$-detector with an area of $30 \mathrm{~mm}^{2}$ and an energy resolution of $135 \mathrm{eV}$ at maximum.

Discrete reference samples are taken from core DE3 and glass beads with a five times dilution are measured by a Philips MagiXPRO via WD-XRF method (Rh-anode, 3.2 KW). The quantification is based on international standards (GovindARAJU 1989). This study also examines whether a quantification of the Eagle III $\mu$ XRF using the standard free fundamental parameter method is suitable. The alternative is using the intensities as relative results in combination with quantified but independent measurements by WD-XRF methodology.

\subsection{Statistical processing of the data}

Core sequences with reworked material were removed from the original data set. High amounts of resin (e.g. cracks caused by sample preparation) were detected by a locally low sum of measured intensities and are subsequently removed. Therefore a threshold of $500 \mathrm{cps}$ was evaluated empirically.

A principal component analysis (PCA) was performed to detect different lithological facies, such as dust, by using inorganic geochemical data. The PCA was used to objectively describe the differences and similarities between the elements and to reduce the number of variables by showing the main variance of the data set by only a few factors. The factor loadings give the correlation between the newly found factor and the respective element. The higher the influence of an element for the factor, the higher is the factor loading. For all cores the following steps were performed before applying the PCA: (a) Using all measured values at $1 \mathrm{~mm}$ resolution results in a total sample amount of several thousands. Hence, data are resampled after smoothing using a Gaussian kernel filter with a 20 point window size to give a sample amount less than 1000 . (b) Most of the parameters exhibited a pronounced skewness. PCA as well as Pearson correlation give unbiased results only for Gaussian distribution, which would be especially crucial for small data sets. However, the data were log transformed and znormalized to zero mean and unit standard derivation for each parameter separately in order to weight equally the different parameters in the multivariate analysis. (c) Subsequently, outliers were removed by deleting values greater/ less than mean plus/minus three time standard derivation of each measured element (includes $99.7 \%$ of all normal distributed values). The amount of significant and nontrivial new variables is measured using the scree test. Sulfur is not considered in the PCA since it correlates less well to the reference values and did not change the major findings of the PCA. However, $S$ is known to be precipitated as pyrite and is thus a proxy for anoxic conditions of the bottom water. The concentration of an element in the lake sediment depends on the amount of influx and the degree of preservation of this element (Engstrom \& Wright 1984). Thus, the new calculated variables (principal component factors) are controlled by the same mechanisms of influx and preservation. For all numerical analysis MATLAB (TheMathworks, version 2009b) were used. 


\section{Results}

\subsection{Calibration of $\mu$ XRF results}

The results of the $\mu \mathrm{XRF}$ scanning are presented as intensities (counts per second, cps). Since core DE3 is one of the most important cores of ELSA, discrete (and destructive) sample analysis using the WD-XRF is obtained to evaluate the intensity values given by the ED-XRF scanner with certain element concentrations (Tab. 1). For most elements (Al, Ti, Fe, Mn, Mg, Ca, Zr) good correlation (R2 > 0.75) can be observed between the intensities counted by the Eagle III $\mu \mathrm{XRF}$ and the corresponding measured concentrations (Tab. 2). The correlation was also checked for the standard-free quantification (fundamental parameter method) for weight percentages and atomic percentages. While the main elements fit quite well, $\mathrm{Zr}$ is the only trace element which shows an acceptable correlation between the measurements by WD-XRF and the intensities but does not have a significant correlation with the quantified results. However, Si matches better with the calculated weight percentages than with the intensity. The elements $\mathrm{Cr}, \mathrm{Ni}, \mathrm{Cu}$, and $\mathrm{Zn}$ which show only weak correlation with the WD-XRF results are not further considered in this study. In the following the intensities are represented for the core SM3 and for DE3 weight\% are shown because of good correlation between the ED- and WD-XRF results.

\subsection{The elemental stratification}

The comparison of the geochemical stratification (Fig. 4, 5) with the lithology of each single core leads to the suggestion, that $\mathrm{Ca}, \mathrm{Si}$ and, $\mathrm{K}$ are the most prominent elements for the classification of aeolian sediments.

Core DE3 covers a time period from MIS3-MIS2, including the glacial inception of the late Weichselian ice sheets. However, single but severe dust events can be found between 43-41 m depth, which corresponds to the marine $\mathrm{H} 4$ event (Hemming 2004), and beginning at $36 \mathrm{~m}$ the content of aeolian sediment is increasing, culminating in the last glacial maximum (LGM). Best correspondence with the lithological stratification can be found with the $\mathrm{Si}, \mathrm{Ca}$, and $\mathrm{Zr}$. The stratification of the elements $\mathrm{Si}, \mathrm{Al}$, and Ti differ in the core DE3 (Fig. 4a, b). Si shows an overall increasing trend over the whole core section (from bottom to top), starting from around $60 \mathrm{wt} .-\%$ up to $70 \mathrm{wt} .-\%$. The core section from 5-25 $\mathrm{m}$ has the highest content of Si with a slight increase between 15-25 $\mathrm{m}$, while content in the core sections from $36-38 \mathrm{~m}$ and $58-60 \mathrm{~m}$ are decreases in relation to the overall trend and corresponding to an increase of organic matter in the sediment. In the core DE3 Ca is obviously enriched $(\mathrm{CaO}$ content around $5 \mathrm{wt} . \%)$ in the upper section, with a depression between 10 and $20 \mathrm{~m}$ depth. Lower down core the content is around $1 \mathrm{wt} .-\%$ and reaches only higher values at $39 \mathrm{~m}$, between $41-45 \mathrm{~m}$, and in places between 59-68 $\mathrm{m}$. The strong shift at $33 \mathrm{~m}$ depth from low to high amounts of $\mathrm{Ca}$ and $\mathrm{Zr}$ coincides with the last glacial ice advance of the late Weichselian, when the climate became colder and dryer and thus deflation processes became more frequent. $\mathrm{Al}$ and $\mathrm{Ti}$ are anti-correlated relating to $\mathrm{Si}$ and $\mathrm{Mg}$ and $\mathrm{K}$ are anti-correlated to $\mathrm{Ca}$, showing a strong decrease between 33 and $25 \mathrm{~m}$. Thus, these elements do not reflect a signal of allogenic aeolian input. Higher amounts of $\mathrm{Al}$ (around 15 wt.-\%) correspond with the increase of gyttja and thus with an increase of chemical weathering due to more precipitation.

In the Holocene core SM3, the elements $\mathrm{Si}, \mathrm{Ti}, \mathrm{Al}, \mathrm{K}$ and $\mathrm{Ca}$ are the most prominent ones to characterize loess gyttja and dust bearing sediment. $\mathrm{Si}, \mathrm{Al}$ and $\mathrm{Ti}$ show corresponding stratigraphic patterns over the whole core (Fig. 5). Highest intensities of these elements are significant for the uppermost core meter and the core section $6.3-12.0 \mathrm{~m}$. The latter is characterized by quite stable intensities of these geogenic elements, corresponding with loess gyttja. SM3 is characterized by a highly correlated stratification of $\mathrm{Mg}$ and $\mathrm{K}$, corresponding to the signal of $\mathrm{Ti}$ and $\mathrm{Al}$. Ca shows significant peaks. In core SM3 certain amounts of $\mathrm{Ca}$ are in the layer 5-5.5 $\mathrm{m}$ and 6.3-7 $\mathrm{m}$ depth. The sections $1-2 \mathrm{~m}$ and 7.5-10 $\mathrm{m}$ are also enriched in $\mathrm{Ca}$. $\mathrm{Al}, \mathrm{Ti}$ and $\mathrm{Mg}$ reaches the highest level in the uppermost meters. Si, K and $\mathrm{Ca}$ are enriched in the deepest part of the core and coincide with the highest dust occurrence of the core. In the core SM3 Zr shows a correlating trend to $\mathrm{Si}, \mathrm{Al}$ and $\mathrm{Ti}$, with maximum values around $2 \mathrm{~m}$ depth and from $6.5 \mathrm{~m}$ on down core. $\mathrm{Sr}$ peaks correspond to the major Ca peaks at $5 \mathrm{~m}$ and at 6.3 $\mathrm{m}$. The latter peak represents the volcanic ash of the LST and shows strongly elevated values of the major geogenic elements, too.

In both cores the elements $\mathrm{Fe}, \mathrm{Mn}, \mathrm{S}$ and $\mathrm{P}$ match to core sections with higher amounts of organic matter and reflect environmental conditions with changing oxygenation of the bottom water or changes of the redox potential at the lake bottom. Over wide parts $\mathrm{Fe}$ and $\mathrm{P}$ correspond to the $\mathrm{Al}$ signal. S is mostly anticorrelated to these elements. This accords with vivianite concretions which are found in the core DE3 between 40 and $70 \mathrm{~m}$ depth. The mineral vivianite, $(\mathrm{Fe})_{3}\left(\mathrm{PO}_{4}\right)_{2}{ }^{*} 8 \mathrm{H}_{2} \mathrm{O}$, might be precipitated in absence of sulphur which would produce pyrite. In DE3 Fe, Mn and P have decreasing trends from the bottom to the top. Fe and $\mathrm{Mn}$ have corresponding trends, too. The $\mathrm{Fe}_{2} \mathrm{O}_{3}$ (total) content increases from $10-5$ wt. $\%$ with an extraordinarily high value of nearly $20 \mathrm{wt} . \%$ at $60 \mathrm{~m}$ depth. The $\mathrm{MnO}$ content is low and reaches a maximum of $1 \mathrm{wt} .-\%$ in $60 \mathrm{~m}$, too. The highest values of $\mathrm{S}$ can be found at the same core sequence from 59 to $64 \mathrm{~m}$ depth. In this section the lost of ignition (LOI) is doubled from around 8 wt.- $\%$ to nearly 18 wt.-\% (Tab. 1a). This section corresponds to the Greenland interstadial GIS14 , which is suggested to be the warmest interstadial of the last glacial cycle. The lowest levels of Fe and $\mathrm{Mn}$ are between $32 \mathrm{~m}$ depth until the top. A dip in their content is found between 40-46 m. Simultaneously Ca, Zr and S are enriched. In SM3 the elements Fe, Mn, P and S stratify the core from bottom to top into four parts and especially $\mathrm{S}$ is anti-correlated to the geogenic elements: (1) the deepest section (up to $7 \mathrm{~m}$ depth) is quite stable and shows only low counts of these elements. (2) Strong increase of S with decreasing Fe values and stable counts of Mn and P follows from 6.5-5.2 m. (3) In the sequence from 5.2 to $2.2 \mathrm{~m}$ all these elements correlate with each other and S shows its maximum values. Indeed, this is the section with the highest amount of organics in the core SM3. (4) In the uppermost section Fe, Mn and P correlate, and $\mathrm{S}$ is nearly anticorrelated to the other elements. 
Tab. 1: WD-XRF results from the core DE3 from the Dehner dry maar, including main elements (upper panel) and trace elements (lower panel).

Tab. 1: WD-XRF-Ergebnisse des Kerns DE3 aus dem Dehner Trockenmaar inklusive Hauptelemente (obere Tafel) und Spurenelemente (untere Tafel).

\begin{tabular}{|c|c|c|c|c|c|c|c|c|c|c|c|c|c|}
\hline Tiefe [m] & $\begin{array}{c}\text { LOI } \\
\text { [wt\%] }\end{array}$ & $\begin{array}{c}\text { SiO2 } \\
\text { [wt\%] }\end{array}$ & $\begin{array}{c}\text { TiO2 } \\
\text { [wt\%] }\end{array}$ & $\begin{array}{l}\text { Al203 } \\
\text { [wt\%] }\end{array}$ & $\begin{array}{c}\mathrm{Fe} 203[\mathrm{t}] \\
{[w t \%]}\end{array}$ & $\begin{array}{c}\mathrm{MnO} \\
{[\mathrm{wt} \%]}\end{array}$ & $\begin{array}{c}\mathrm{MgO} \\
{[w t \%]}\end{array}$ & $\begin{array}{c}\mathrm{CaO} \\
{[\mathrm{wt} \%]}\end{array}$ & $\begin{array}{l}\text { Na2O } \\
\text { [wt\%] }\end{array}$ & $\begin{array}{c}\text { K20 } \\
\text { [wt\%] }\end{array}$ & $\begin{array}{l}\text { P205 } \\
\text { [wt\%] }\end{array}$ & $\begin{array}{c}\mathrm{SO3} \\
\text { [wt\%] }\end{array}$ & $\begin{array}{l}\text { Sum } \\
{[\%]}\end{array}$ \\
\hline 4.50 & 7.05 & 74.28 & 0.95 & 10.59 & 4.41 & 0.09 & 1.54 & 4.26 & 0.68 & 2.39 & 0.12 & 0.404 & 99.7 \\
\hline 6.49 & 7.68 & 73.93 & 0.96 & 10.87 & 4.45 & 0.07 & 1.56 & 4.96 & 0.66 & 2.43 & 0.11 & 0.472 & 100.5 \\
\hline 8.70 & 7.45 & 73.58 & 1.02 & 11.39 & 4.81 & 0.07 & 1.64 & 4.52 & 0.67 & 2.49 & 0.13 & 0.452 & 100.8 \\
\hline 10.60 & 6.14 & 78.70 & 1.08 & 8.05 & 3.40 & 0.06 & 1.33 & 4.72 & 0.74 & 1.98 & 0.11 & 0.422 & 100.6 \\
\hline 14.50 & 6.56 & 75.87 & 0.98 & 10.60 & 4.32 & 0.07 & 1.54 & 3.67 & 0.73 & 2.37 & 0.12 & 0.322 & 100.6 \\
\hline 20.10 & 6.68 & 75.68 & 1.05 & 10.80 & 4.21 & 0.06 & 1.49 & 3.58 & 0.73 & 2.31 & 0.11 & 0.225 & 100.3 \\
\hline 21.78 & 6.33 & 79.17 & 0.91 & 8.05 & 2.93 & 0.06 & 1.33 & 4.73 & 0.85 & 1.93 & 0.09 & 0.225 & 100.3 \\
\hline 23.45 & 6.73 & 77.60 & 0.96 & 8.85 & 3.39 & 0.06 & 1.48 & 4.97 & 0.8 & 2.03 & 0.11 & 0.207 & 100.5 \\
\hline 29.50 & 7.84 & 71.78 & 0.99 & 12.55 & 4.71 & 0.09 & 2.01 & 4.70 & 0.78 & 2.64 & 0.16 & 0.175 & 100.6 \\
\hline 33.50 & 6.30 & 69.05 & 1.15 & 16.16 & 6.23 & 0.11 & 2.11 & 1.51 & 0.72 & 3.19 & 0.18 & 0.062 & 100.5 \\
\hline 39.55 & 6.41 & 67.84 & 1.25 & 17.00 & 6.8 & 0.09 & 2.00 & 1.25 & 0.68 & 3.27 & 0.20 & 0.022 & 100.4 \\
\hline 41.31 & 9.61 & 55.75 & 1.01 & 26.20 & 8.53 & 0.09 & 2.2 & 1.04 & 0.36 & 4.96 & 0.20 & 0.035 & 100.4 \\
\hline 41.45 & 6.73 & 69.14 & 1.16 & 15.18 & 5.99 & 0.11 & 2.05 & 2.41 & 0.75 & 3.00 & 0.19 & 0.117 & 100.1 \\
\hline 43.81 & 7.07 & 69.16 & 1.17 & 15.33 & 6.14 & 0.09 & 2.09 & 2.55 & 0.76 & 2.98 & 0.20 & 0.119 & 100.6 \\
\hline 49.50 & 7.31 & 66.31 & 1.39 & 17.90 & 7.44 & 0.09 & 2.09 & 1.16 & 0.64 & 3.20 & 0.27 & 0.022 & 100.5 \\
\hline 52.50 & 7.20 & 66.00 & 1.55 & 16.31 & 8.08 & 0.15 & 2.73 & 1.93 & 0.51 & 2.70 & 0.30 & 0.023 & 100.3 \\
\hline 57.51 & 8.09 & 63.86 & 1.77 & 18.05 & 9.30 & 0.16 & 2.16 & 1.39 & 0.46 & 2.86 & 0.35 & 0.011 & 100.4 \\
\hline 59.57 & 16.98 & 59.15 & 1.22 & 12.72 & 19.42 & 0.93 & 1.52 & 1.52 & 0.23 & 1.96 & 2.04 & 0.025 & 100.7 \\
\hline 63.26 & 16.50 & 66.05 & 1.47 & 14.57 & 10.33 & 0.45 & 1.91 & 1.69 & 0.27 & 2.26 & 1.46 & 0.086 & 100.6 \\
\hline 68.47 & 9.05 & 60.60 & 1.48 & 20.83 & 9.11 & 0.18 & 2.53 & 1.08 & 0.47 & 3.70 & 0.30 & 0.03 & 100.3 \\
\hline 68.63 & 10.05 & 56.71 & 1.37 & 19.81 & 12.35 & 0.21 & 2.42 & 0.97 & 0.43 & 3.58 & 2.38 & 0.018 & 100.3 \\
\hline 71.70 & 8.69 & 61.19 & 1.44 & 20.59 & 8.66 & 0.11 & 2.43 & 1.04 & 0.48 & 3.74 & 0.36 & 0.03 & 100.1 \\
\hline 77.88 & 6.75 & 62.61 & 1.35 & 19.59 & 8.12 & 0.08 & 2.82 & 1.40 & 0.47 & 3.70 & 0.22 & 0.023 & 100.4 \\
\hline 80.70 & 7.04 & 61.02 & 1.19 & 19.84 & 8.12 & 0.15 & 2.54 & 2.03 & 0.48 & 3.79 & 0.92 & 0.01 & 100.1 \\
\hline 83.31 & 10.19 & 61.64 & 1.44 & 20.10 & 8.07 & 0.08 & 2.84 & 1.83 & 0.45 & 3.57 & 0.26 & 0.043 & 100.3 \\
\hline
\end{tabular}

\begin{tabular}{|l|l|l|l|l|l|l|l|l|l|l|l|l|l|l|l|}
\hline Tiefe & $\mathbf{V}$ & $\mathbf{C r}$ & $\mathbf{C o}$ & $\mathrm{Ni}$ & $\mathbf{C u}$ & $\mathrm{Zn}$ & $\mathbf{R b}$ & $\mathrm{Sr}$ & $\mathrm{Y}$ & $\mathrm{Zr}$ & $\mathrm{Nb}$ & $\mathbf{B a}$ & $\mathbf{P b}$ & $\mathbf{L a}$ & $\mathbf{C e}$ \\
\hline
\end{tabular}

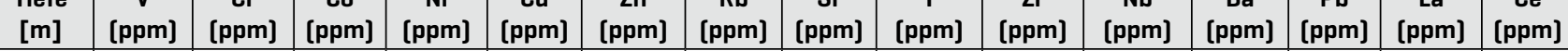

\begin{tabular}{|l|l|l|l|l|l|l|l|l|l|l|l|l|c|c|c|}
\hline $\mathbf{4 . 5 0}$ & 79 & 97 & 13 & 33 & 18 & 54 & 90 & 132 & 36 & 545 & 19 & 379 & 21 & 42 & 85 \\
\hline
\end{tabular}

\begin{tabular}{|l|l|l|l|l|l|l|l|l|l|l|l|l|l|l|l|l|}
$\mathbf{6 . 4 9}$ & 80 & 98 & 13 & 31 & 22 & 62 & 94 & 142 & 37 & 541 & 20 & 391 & 21 & 46 & 79 \\
\hline
\end{tabular}

\begin{tabular}{|l|l|l|l|l|l|l|l|l|l|l|l|l|l|l|l|l|}
$\mathbf{8 . 7 0}$ & 80 & 103 & 15 & 37 & 34 & 61 & 96 & 137 & 39 & 551 & 19 & 401 & 19 & 41 & 84 \\
\hline
\end{tabular}

\begin{tabular}{|l|l|l|l|l|l|l|l|l|l|l|l|l|l|l|l|}
\hline $\mathbf{1 0 . 6 0}$ & 60 & 110 & 8 & 24 & 13 & 46 & 69 & 134 & 45 & 956 & 22 & 344 & 20 & 48 & 84 \\
\hline
\end{tabular}

\begin{tabular}{|l|l|l|l|l|l|l|l|l|l|l|l|l|l|l|l|l|}
\hline $\mathbf{1 4 . 5 0}$ & 78 & 105 & 13 & 34 & 15 & 57 & 91 & 128 & 38 & 615 & 20 & 367 & 18 & 47 & 90 \\
\hline
\end{tabular}

\begin{tabular}{|l|l|l|l|l|l|l|l|l|l|l|l|l|l|l|l|}
\hline $\mathbf{2 0 . 1 0}$ & 77 & 104 & 11 & 30 & 16 & 58 & 90 & 131 & 41 & 649 & 20 & 387 & 19 & 50 & 87 \\
\hline
\end{tabular}

\begin{tabular}{|l|l|l|l|l|l|l|l|l|l|l|l|l|l|l|l|l}
$\mathbf{2 1 . 7 8}$ & 48 & 91 & 4 & 20 & 10 & 41 & 70 & 141 & 38 & 721 & 19 & 347 & 16 & 51 & 79 \\
\hline
\end{tabular}

\begin{tabular}{|l|l|l|l|l|l|l|l|l|l|l|l|l|l|l|l|}
$\mathbf{2 3 . 4 5}$ & 59 & 99 & 8 & 29 & 14 & 48 & 73 & 143 & 39 & 681 & 19 & 337 & 16 & 42 & 82 \\
\hline
\end{tabular}

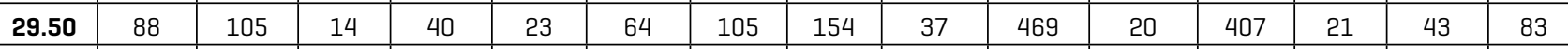

\begin{tabular}{|l|l|l|l|l|l|l|l|l|l|l|l|l|l|l|l|l|}
$\mathbf{3 3 . 5 0}$ & 122 & 120 & 20 & 53 & 34 & 81 & 135 & 160 & 38 & 368 & 23 & 535 & 23 & 60 & 99 \\
\hline
\end{tabular}

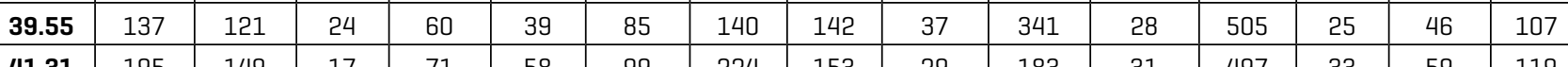

\begin{tabular}{|l|l|l|l|l|l|l|l|l|l|l|l|l|l|l|l|l|l|}
\hline $\mathbf{4 1 . 3 1}$ & 195 & 149 & 17 & 71 & 58 & 99 & 224 & 153 & 29 & 183 & 31 & 497 & 33 & 59 & 119 \\
\hline
\end{tabular}

\begin{tabular}{|l|l|l|l|l|l|l|l|l|l|l|l|l|l|l|l|l|}
\hline $\mathbf{4 1 . 4 5}$ & 117 & 113 & 21 & 52 & 40 & 76 & 126 & 150 & 37 & 380 & 26 & 486 & 21 & 49 & 102 \\
\hline
\end{tabular}

\begin{tabular}{|l|l|l|l|l|l|l|l|l|l|l|l|l|l|l|l|l|}
\hline 43.81 & 121 & 109 & 17 & 54 & 39 & 78 & 125 & 164 & 38 & 379 & 28 & 532 & 21 & 50 & 104 \\
\hline
\end{tabular}

\begin{tabular}{|l|l|l|l|l|l|l|l|l|l|l|l|l|l|l|l}
$\mathbf{4 9 . 5 0}$ & 160 & 133 & 23 & 62 & 54 & 91 & 149 & 184 & 36 & 313 & 37 & 623 & 24 & 62 & 115 \\
\hline
\end{tabular}

\begin{tabular}{|l|l|l|l|l|l|l|l|l|l|l|l|l|l|l|l|l|}
\hline $\mathbf{5 2 . 5 0}$ & 179 & 161 & 26 & 87 & 105 & 91 & 127 & 189 & 35 & 303 & 42 & 667 & 24 & 57 & 117 \\
\hline
\end{tabular}

\begin{tabular}{|l|l|l|l|l|l|l|l|l|l|l|l|l|l|l|l|l|}
$\mathbf{5 7 . 5 1}$ & 201 & 156 & 26 & 80 & 71 & 92 & 136 & 180 & 38 & 345 & 51 & 705 & 25 & 63 & 118 \\
\hline
\end{tabular}

\begin{tabular}{|l|l|l|l|l|l|l|l|l|l|l|l|l|l|l|l|l|}
$\mathbf{5 9 . 5 7}$ & 220 & 106 & 22 & 76 & 74 & 91 & 99 & 134 & 24 & 166 & 42 & 568 & 22 & 49 & 99 \\
\hline
\end{tabular}

\begin{tabular}{|l|l|l|l|l|l|l|l|l|l|l|l|l|l|l|l|l|}
\hline $\mathbf{6 3 . 2 6}$ & 260 & 109 & 30 & 82 & 93 & 107 & 115 & 158 & 26 & 187 & 53 & 735 & 23 & 66 & 114 \\
\hline
\end{tabular}

\begin{tabular}{|l|l|l|l|l|l|l|l|l|l|l|l|l|l|l|l|}
\hline $\mathbf{6 8 . 4 7}$ & 215 & 146 & 36 & 88 & 87 & 120 & 170 & 151 & 34 & 222 & 40 & 625 & 35 & 65 & 140 \\
\hline $\mathbf{6 8 . 6 3}$ & 199 & 132 & 33 & 79 & 67 & 112 & 158 & 148 & 34 & 205 & 39 & 612 & 30 & 56 & 118 \\
\hline $\mathbf{7 1 . 7 0}$ & 205 & 151 & 32 & 82 & 75 & 113 & 168 & 149 & 34 & 228 & 37 & 567 & 33 & 70 & 131 \\
\hline $\mathbf{7 7 . 8 8}$ & 176 & 142 & 30 & 79 & 74 & 104 & 156 & 233 & 35 & 238 & 33 & 669 & 30 & 69 & 123 \\
\hline $\mathbf{8 0 . 7 0}$ & 164 & 139 & 27 & 76 & 62 & 96 & 164 & 225 & 34 & 226 & 29 & 573 & 33 & 56 & 117 \\
\hline $\mathbf{8 3 . 3 1}$ & 284 & 135 & 29 & 75 & 102 & 110 & 154 & 174 & 33 & 216 & 45 & 573 & 32 & 76 & 134 \\
\hline
\end{tabular}


Tab. 2: Correlation of DE3 $\mu X R F$ results (Intensity, Wt\%, At\%) with WD-XRF analysis. In general, the main elements show the highest correlations, at least in comparison with the measured intensity values with the WD-XRF results. Italic printed values are not significant at the 0.05 level. Highest values of correlation are highlighted with bold letters.

Tab. 2: Korrelationsergebnisse (DE3) der $\mu$ XRF-Resultate (Intensität, Gew.-\%, Atom.-\%) mit den WD-XRF-Analysen an diskreten Proben. Höchste Korrelationen sind hervorgehoben. Kursiv gedruckte Werte sind auf dem Niveau von 0,05 nicht signifikant. Höchste Korrelationen sind fett hervorgehoben.

\begin{tabular}{|l|c|c|c|c|}
\hline & $\begin{array}{c}\text { Si02 [Wt\%] } \\
\text { WD }\end{array}$ & Si - Int. & Si - Wt\% & Si - At\% \\
\hline Si02 [\%] WD & 1.00 & & & \\
\hline Si - Int. & 0.41 & 1.00 & & \\
\hline Si - Wt\% & $\mathbf{0 . 6 9}$ & 0.81 & 1.00 & \\
\hline Si - At\% & 0.53 & 0.74 & 0.97 & 1.00 \\
\hline
\end{tabular}

\begin{tabular}{|l|c|c|c|c|}
\hline & $\begin{array}{c}\text { Na20 [Wt \%] } \\
\text { WD }\end{array}$ & Na - Int. & Na - Wt\% & Na - At\% \\
\hline Na20 [\%] WD & 1.00 & & & \\
\hline $\mathrm{Na}-$ Int. & $\mathbf{0 . 4 1}$ & 1.00 & & \\
\hline $\mathrm{Na}-\mathbf{W t} \%$ & 0.20 & 0.11 & 1.00 & \\
\hline $\mathrm{Na}-$ At\% & 0.17 & 0.10 & 1.00 & 1.00 \\
\hline
\end{tabular}

\begin{tabular}{|l|c|c|c|c|}
\hline & $\begin{array}{c}\text { Ti02 [Wt\%] } \\
\text { WD }\end{array}$ & Ti- Int. & Ti - Wt\% & Ti- At\% \\
\hline Ti02 [\%] WD & 1.00 & & & \\
\hline Ti- Int. & $\mathbf{0 . 8 4}$ & 1.00 & & \\
\hline $\mathrm{Ti}-\mathbf{W t} \%$ & 0.70 & 0.86 & 1.00 & \\
\hline $\mathrm{Ti}-\mathbf{A t} \%$ & 0.71 & 0.82 & 0.98 & 1.00 \\
\hline
\end{tabular}

\begin{tabular}{|l|c|c|c|c|}
\hline & $\begin{array}{c}\text { Cr [ppm] } \\
\text { WD }\end{array}$ & Cr - Int. & Cr - Wt\% & Cr - At\% \\
\hline Cr [ppm] WD & 1.00 & & & \\
\hline Cr - Int. & $-\mathbf{0 . 3 2}$ & 1.00 & & \\
\hline Cr - Wt\% & -0.31 & 0.28 & 1.00 & \\
\hline Cr - At\% & $\mathbf{- 0 . 3 2}$ & 0.33 & 0.98 & 1.00 \\
\hline
\end{tabular}

\begin{tabular}{|l|c|c|c|c|}
\hline & $\begin{array}{c}\text { Al203 } \\
\text { [Wt\%] WD }\end{array}$ & Al - Int. & Al - Wt\% & Al - At\% \\
\hline Al203 [\%] WD & 1.00 & & & \\
\hline Al - Int. & 0.66 & 1.00 & & \\
\hline Al - Wt\% & 0.74 & 0.95 & 1.00 & \\
\hline Al - At\% & $\mathbf{0 . 8 2}$ & 0.91 & 0.98 & 1.00 \\
\hline
\end{tabular}

\begin{tabular}{|l|c|c|c|c|}
\hline & $\begin{array}{c}\text { Ni [ppm] } \\
\text { WD }\end{array}$ & Ni- Int. & Ni- Wt\% & Ni - At\% \\
\hline $\mathbf{N i}$ [ppm] WD & 1.00 & & & \\
\hline $\mathbf{N i}-$ Int. & $-\mathbf{0 . 2 1}$ & 1.00 & & \\
\hline $\mathbf{N i}-\mathbf{W t \%}$ & -0.03 & 0.38 & 1.00 & \\
\hline $\mathbf{N i}-\mathbf{A t} \%$ & 0.10 & 0.37 & 0.94 & 1.00 \\
\hline
\end{tabular}

\begin{tabular}{|l|c|c|c|c|}
\hline & $\begin{array}{c}\text { Fe203[t] } \\
{[W t \%] \text { WD }}\end{array}$ & Fe - Int. & Fe - Wt\% & Fe - At\% \\
\hline $\begin{array}{l}\text { Fe203[t][\%] } \\
\text { WD }\end{array}$ & 1.00 & & & \\
\hline Fe - Int. & 0.95 & 1.00 & & \\
\hline Fe-Wt\% & 0.95 & 0.85 & 1.00 & \\
\hline Fe-At\% & 0.93 & 0.82 & 1.00 & 1.00 \\
\hline
\end{tabular}

\begin{tabular}{|l|c|c|c|c|}
\hline & Cu [ppm] WD & Cu - Int. & Cu - Wt\% & Cu - At\% \\
\hline Cu [ppm] WD & 1.00 & & & \\
\hline Cu - Int. & $-\mathbf{0 . 2 4}$ & 1.00 & & \\
\hline Cu - Wt\% & -0.18 & 0.05 & 1.00 & \\
\hline Cu - At\% & -0.05 & -0.15 & 0.95 & 1.00 \\
\hline
\end{tabular}

\begin{tabular}{|l|c|c|c|c|}
\hline & $\begin{array}{c}\text { MnO [Wt\%] } \\
\text { WD }\end{array}$ & Mn - Int. & Mn - Wt\% & Mn - At\% \\
\hline MnO [\%] WD & 1.00 & & & \\
\hline Mn - Int. & $\mathbf{0 . 9 9}$ & 1.00 & & \\
\hline Mn - Wt\% & 0.98 & 0.98 & 1.00 & \\
\hline Mn - At\% & 0.98 & 0.97 & 1.00 & 1.00 \\
\hline
\end{tabular}

\begin{tabular}{|l|c|c|c|c|}
\hline & Zn [ppm] WD & Zn - Int. & Zn - Wt\% & Zn - At\% \\
\hline Zn [ppm] WD & 1.00 & & & \\
\hline Zn - Int. & $-\mathbf{0 . 3 5}$ & 1.00 & & \\
\hline Zn - Wt\% & -0.10 & 0.60 & 1.00 & \\
\hline Zn - At\% & -0.01 & 0.46 & 0.94 & 1.00 \\
\hline
\end{tabular}

\begin{tabular}{|l|c|c|c|c|}
\hline & $\begin{array}{c}\text { MgO [Wt\%] } \\
\text { WD }\end{array}$ & Mg- Int. & Mg- Wt\% & Mg-At\% \\
\hline MgO [\%] WD & 1.00 & & & \\
\hline Mg - Int. & $\mathbf{0 . 8 2}$ & 1.00 & & \\
\hline Mg - Wt\% & 0.72 & 0.77 & 1.00 & \\
\hline Mg - At\% & 0.79 & 0.81 & 0.99 & 1.00 \\
\hline
\end{tabular}

\begin{tabular}{|l|c|c|c|c|}
\hline & $\begin{array}{c}\text { Sr [ppm] } \\
\text { WD }\end{array}$ & Sr - Int. & Sr - Wt\% & Sr - At\% \\
\hline Sr [ppm] WD & 1.00 & & & \\
\hline Sr - Int. & 0.17 & 1.00 & & \\
\hline Sr - Wt\% & -0.34 & 0.28 & 1.00 & \\
\hline Sr - At\% & $\mathbf{- 0 . 3 7}$ & 0.18 & 0.98 & 1.00 \\
\hline
\end{tabular}

\begin{tabular}{|l|c|c|c|c|}
\hline & $\begin{array}{c}\text { CaO [Wt\%] } \\
\text { WD }\end{array}$ & Ca - Int. & Ca - Wt\% & Ca - At\% \\
\hline CaO [\%] WD & 1.00 & & & \\
\hline Ca - Int. & $\mathbf{0 . 9 8}$ & 1.00 & & \\
\hline Ca - Wt\% & 0.96 & 0.98 & 1.00 & \\
\hline Ca - At\% & 0.96 & 0.98 & 1.00 & 1.00 \\
\hline
\end{tabular}

\begin{tabular}{|l|c|c|c|c|}
\hline & $\begin{array}{c}\text { Zr [ppm] } \\
\text { WD }\end{array}$ & Zr - Int. & Zr - Wt\% & Zr - At\% \\
\hline Zr [ppm] WD & 1.00 & & & \\
\hline Zr - Int. & $\mathbf{0 . 7 8}$ & 1.00 & & \\
\hline Zr - Wt\% & 0.39 & 0.02 & 1.00 & \\
\hline Zr - At\% & 0.24 & -0.10 & 0.96 & 1.00 \\
\hline
\end{tabular}



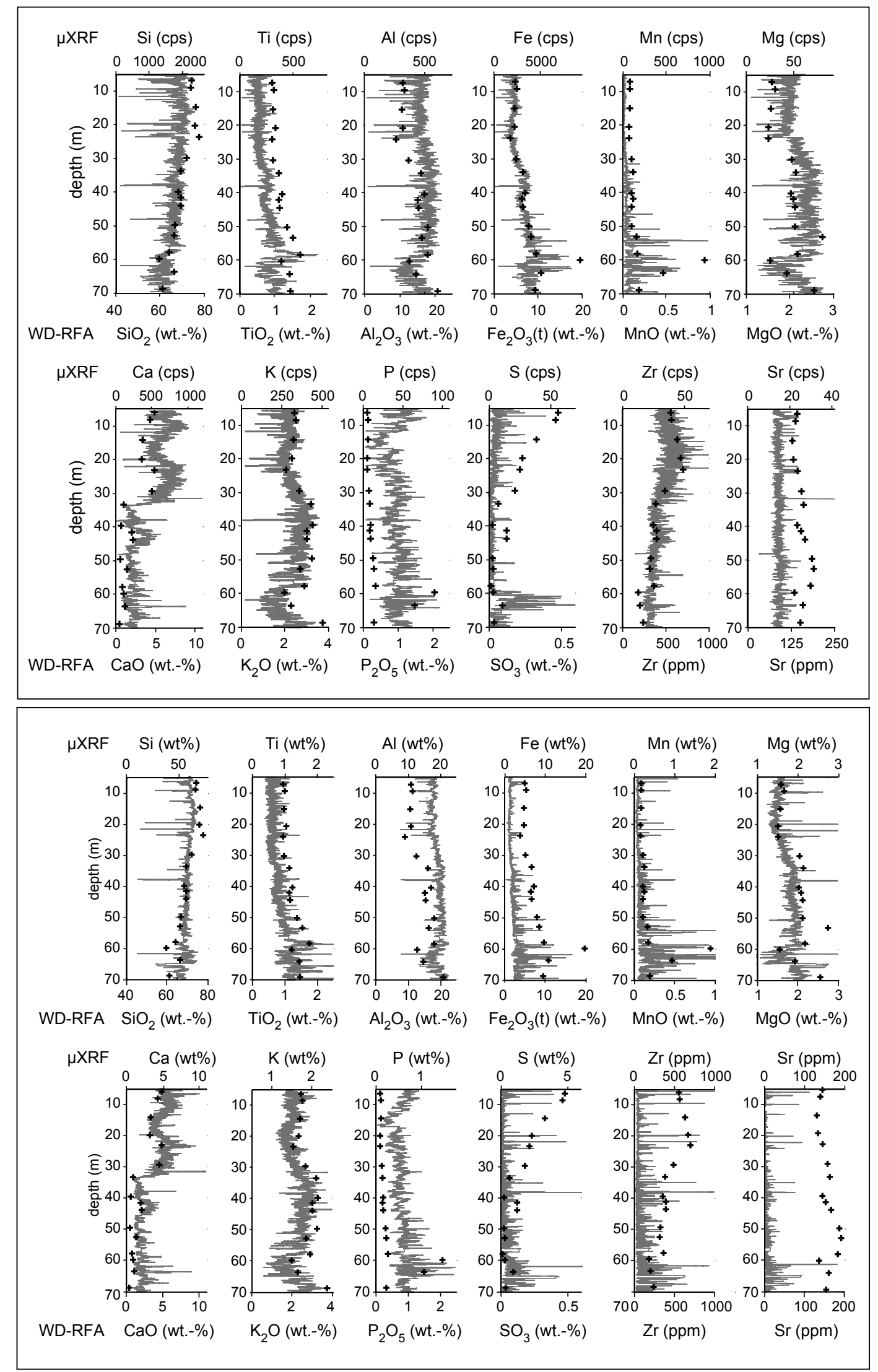

Fig. 4: Continuous measured element concentrations of the core DE3 in (upper panel) cps and (lower panel) quantified (expressed as wt.-\% and ppm) using fundamental parameter method (smoothed by a 50-point running mean filter) and measured with the Eagle III $\mu$ XRF. Black crosses are corresponding results from WD-XRF, measured on discrete samples. Apart from Al all energy dispersive measured elements are underrepresented but show clearly covarying trends. The Ca values represent a dust signal (DIETRICH \& SIROCKO 2009).

Abb. 4: Mit der $\mu R F A$ kontinuierlich gemessene Elementkonzentrationen des Sedimentkerns DE3, angegeben in (upper panel) counts per second (cps) und (lower panel) quantifiziert mittels der Fundamentalparametermethode in Gew.-\% (ppm). Die Werte wurden durch einen gleitenden Mittelwert (Fensterbreite 50-Punkt) geglättet. Die schwarzen Kreuze entsprechen den Vergleichsmessungen an diskreten Proben, die mit einer WD-RFA bestimmt wurden. Mit Ausnahme von Aluminium, zeigen die energie-dispersiv gemessenen Werte niedrigere Konzentrationen an. Insgesamt zeigt die Elementverteilung mit beiden Methoden aber eine deutliche Kovarianz. Hohe Kalziumwerte weisen auf eine verstärkte Staubaktivität hin (DIETRICH \& SIROCKO 2009). 


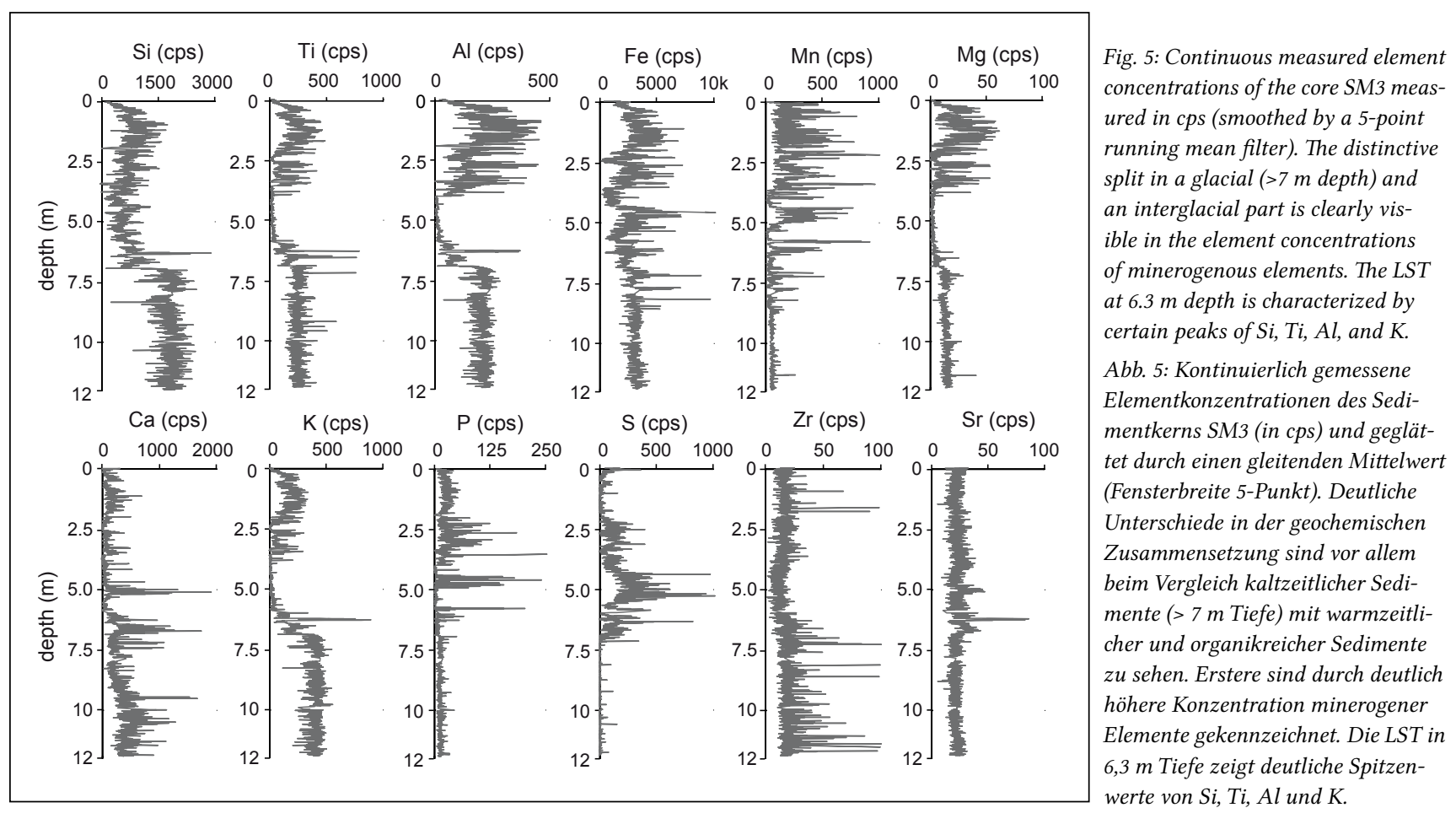

Tab. 3: Upper panel: Correlation matrix of main elements (core DE3 measured intensities by $\mu X R F$ ). Italic printed values are not significant at the 0.05 level. Lower panel: Factor loadings after PCA calculation of main elements (core DE3 measured intensities by $\mu X R F)$, including Eigenwert (Eigen.), the described variance (dVar.) and the cumulative sum of dVar (\% Cumul). Bold printed values ( $\geq|0.4|)$ have a major influence on the single principle components.

Tab. 3: Obere Tafel: Korrelationsmatrix (DE3) der Hauptelemente auf Basis der mittels $\mu$ XRF gemessenen Intensitäten. Kursiv gedruckte Werte sind auf dem Niveau von 0,05 nicht signifikant. Untere Tafel: Faktorladungen der Hauptkomponentenanalyse, inklusive der Eigenwerte (Eigen.) und der jeweiligen beschriebenen Varianz (dVar.). Fett gedruckte Werte $(\geq|0.4|)$ haben einen hohen Einfluß auf die einzelnen Hauptkomponenten.

\begin{tabular}{|l|l|l|l|l|l|l|l|l|l|}
\hline & $\mathbf{M g}$ & $\mathbf{A l}$ & $\mathbf{S i}$ & $\mathbf{P}$ & $\mathbf{K}$ & $\mathbf{C a}$ & $\mathbf{T i}$ & $\mathbf{M n}$ & $\mathbf{F e}$ \\
\hline $\mathbf{M g}$ & 1 & 0.88 & 0.10 & 0.43 & 0.77 & -0.48 & 0.56 & 0.29 & 0.58 \\
\hline $\mathbf{A l}$ & 0.88 & 1 & 0.52 & 0.38 & 0.80 & -0.24 & 0.28 & 0.05 & 0.29 \\
\hline $\mathbf{S i}$ & 0.10 & 0.52 & 1 & -0.15 & 0.40 & 0.40 & -0.40 & -0.45 & -0.42 \\
\hline $\mathbf{P}$ & 0.43 & 0.38 & -0.15 & 1 & 0.11 & -0.21 & 0.25 & 0.40 & 0.35 \\
\hline $\mathbf{K}$ & 0.77 & 0.80 & 0.40 & 0.11 & 1 & -0.27 & 0.20 & 0.00 & 0.28 \\
\hline $\mathbf{C a}$ & -0.48 & -0.24 & 0.40 & -0.21 & -0.27 & 1 & -0.72 & -0.54 & -0.82 \\
\hline $\mathbf{T i}$ & 0.56 & 0.28 & -0.40 & 0.25 & 0.20 & -0.72 & 1 & 0.59 & 0.88 \\
\hline $\mathbf{M n}$ & 0.29 & 0.05 & -0.45 & 0.40 & 0.00 & -0.54 & 0.59 & 1 & 0.79 \\
\hline $\mathbf{F e}$ & 0.58 & 0.29 & -0.42 & 0.35 & 0.28 & -0.82 & 0.88 & 0.79 & 1 \\
\hline
\end{tabular}

\begin{tabular}{|l|l|l|l|l|l|l|l|l|l|}
\hline & PC 1 & PC 2 & PC 3 & PC 4 & PC 5 & PC 6 & PC 7 & PC 8 & PC 9 \\
\hline Eigen & 4.27 & 2.55 & 0.93 & 0.45 & 0.33 & 0.29 & 0.12 & 0.04 & 0.01 \\
\hline dVar. & $53.3 \%$ & $22.4 \%$ & $9.2 \%$ & $5.2 \%$ & $4.6 \%$ & $3.8 \%$ & $1.0 \%$ & $0.6 \%$ & $0.1 \%$ \\
\hline \% Cumul. & $53.3 \%$ & $75.7 \%$ & $84.9 \%$ & $90.1 \%$ & $94.7 \%$ & $98.4 \%$ & $99.4 \%$ & $99.9 \%$ & $100.0 \%$ \\
\hline $\mathbf{M g}$ & 0.21 & 0.34 & -0.10 & 0.11 & -0.15 & 0.20 & $\mathbf{- 0 . 6 0}$ & -0.25 & $\mathbf{0 . 5 9}$ \\
\hline $\mathbf{A l}$ & 0.10 & 0.39 & -0.13 & 0.01 & -0.09 & -0.09 & $\mathbf{- 0 . 4 4}$ & -0.10 & $\mathbf{- 0 . 7 7}$ \\
\hline $\mathbf{S i}$ & -0.22 & $\mathbf{0 . 5 4}$ & 0.00 & $\mathbf{- 0 . 4 8}$ & 0.08 & $\mathbf{- 0 . 5 9}$ & 0.14 & 0.01 & 0.22 \\
\hline $\mathbf{P}$ & 0.17 & 0.06 & $\mathbf{- 0 . 8 1}$ & 0.38 & -0.13 & -0.24 & 0.28 & 0.09 & 0.06 \\
\hline $\mathbf{K}$ & 0.14 & $\mathbf{0 . 6 3}$ & 0.12 & 0.14 & 0.21 & $\mathbf{0 . 5 3}$ & 0.39 & 0.27 & -0.02 \\
\hline $\mathbf{C a}$ & $\mathbf{- 0 . 4 8}$ & 0.00 & -0.38 & $\mathbf{- 0 . 4 4}$ & $\mathbf{- 0 . 4 0}$ & $\mathbf{0 . 4 9}$ & 0.10 & -0.17 & -0.05 \\
\hline $\mathbf{T i}$ & $\mathbf{0 . 4 9}$ & -0.02 & 0.18 & -0.26 & $\mathbf{- 0 . 7 0}$ & -0.06 & 0.08 & $\mathbf{0 . 4 0}$ & 0.01 \\
\hline $\mathbf{M n}$ & $\mathbf{0 . 3 6}$ & -0.19 & -0.35 & $\mathbf{- 0 . 5 3}$ & $\mathbf{0 . 5 0}$ & 0.16 & -0.22 & 0.32 & 0.01 \\
\hline $\mathbf{F e}$ & $\mathbf{0 . 5 0}$ & -0.02 & 0.02 & -0.21 & 0.05 & 0.02 & 0.36 & $\mathbf{- 0 . 7 5}$ & -0.07 \\
\hline
\end{tabular}




\subsection{From geochemical stratification towards a dust signal}

PCA is applied to reduce the amount of variables and to achieve an integrated signal which corresponds better to the lithology of the sediment than the single element stratications. In both cores the first principle component factor (PC 1) illustrated the change from facies containing glacial and aeolian sediment to those which are characterized by containing organic gyttja (Fig. 6). The discrimination into these two lithological groups gives reliable results for SM3 and DE3, which is also indicated by the described variances of the PC 1. This factor accounts for 53.3\% in DE3 and for $56.9 \%$ in SM3, respectively (Tab. 3, 4). However, both cores show different factor loadings for the first variable. In core SM3 the main geogenic elements $\mathrm{Si}, \mathrm{Ti}$, and $\mathrm{K}$ represent those samples which are derived from aeolian sediment. In SM3 Calcium is an additional element characteristic of loess gyttja, and is also the most prominent element in the core DE3. The interpretation of the second PCA variable (PC 2) is more difficult, because of even larger differences between the single cores. In SM3 the PC 2 includes variables with high factor loadings on typical limnogenic and redox-sensitive elements like $\mathrm{Mn}, \mathrm{Fe}$, and $\mathrm{P}$. High values of $\mathrm{P}$ are provided by oxic decay of organic matter. Fe and $\mathrm{Mn}$ can be used to indicate the redox conditions of the lake water (ENGSTROM \& WRIGHT 1984). When the lake is under anoxic conditions, Fe and $\mathrm{Mn}$ are present in soluble form and are easily released from the sediment. In DE3 the geogenic elements are the major contributors on PC 2. These elements are common constituents of primary minerals. Thus PC 2, with high factor loadings on geogenic elements, reflects the intensity of chemical weathering and leaching in the watershed and shows positive values from $35 \mathrm{~m}$ depth down core in DE3.

Summarizing these results one can find that analyses of the first principal component separates glacial and aeolian dominated sediment from interglacial/interstadial organicrich matter. However, in each core the elements with highest loadings differ in the respective factor. In SM3 the geogenic elements are those which characterize the first PC. In the core DE3 the geogenic elements describe the second PC, whereas $\mathrm{Ca}$ and Si are the most important elements for classification of the glacial sediment in PC 1 . On the other hand redox-sensitive elements like $\mathrm{Mn}$ and $\mathrm{P}$ have high loadings in PC 2 for core SM3 and are an indicator for

Tab. 4: Upper panel: Correlation matrix of main elements (core SM3 measured intensities by $\mu X R F)$. Italic printed values are not significant at the 0.05 level. Lower panel: Factor loadings after PCA calculation of main elements (core SM3 measured intensities by $\mu X R F)$, including Eigenwert (Eigen.), the described variance (dVar.) and the cumulative sum of dVar (\% Cumul). Bold printed values ( $\geq|0.4|)$ have a major influence on the single principle components.

Tab. 4: Obere Tafel: Korrelationsmatrix (SM3) der Hauptelemente auf Basis der mittels $\mu$ XRF gemessenen Intensitäten. Kursiv gedruckte Werte sind auf dem Niveau von 0,05 nicht signifikant. Untere Tafel: Faktorladungen der Hauptkomponentenanalyse, inklusive der Eigenwerte (Eigen.) und der jeweiligen beschriebenen Varianz (dVar.). Fett gedruckte Werte $(\geq|0.4|)$ haben einen hohen Einfluß auf die einzelnen Hauptkomponenten.

\begin{tabular}{|l|l|l|l|l|l|l|l|l|l|}
\hline & $\mathbf{M g}$ & $\mathbf{A l}$ & $\mathbf{S i}$ & $\mathbf{P}$ & $\mathbf{K}$ & $\mathbf{C a}$ & $\mathbf{T i}$ & $\mathbf{M n}$ & $\mathbf{F e}$ \\
\hline $\mathbf{M g}$ & 1 & 0.88 & 0.59 & 0.47 & 0.75 & 0.42 & 0.85 & 0.08 & 0.54 \\
\hline $\mathbf{A l}$ & 0.88 & 1 & 0.67 & 0.52 & 0.81 & 0.40 & 0.89 & 0.02 & 0.48 \\
\hline $\mathbf{S i}$ & 0.59 & 0.67 & 1 & 0.07 & 0.85 & 0.66 & 0.74 & -0.35 & 0.50 \\
\hline $\mathbf{P}$ & 0.47 & 0.52 & 0.07 & 1 & 0.12 & -0.16 & 0.30 & 0.60 & 0.38 \\
\hline $\mathbf{K}$ & 0.75 & 0.81 & 0.85 & 0.12 & 1 & 0.69 & 0.94 & -0.31 & 0.56 \\
\hline $\mathbf{C a}$ & 0.42 & 0.40 & 0.66 & -0.16 & 0.69 & 1 & 0.61 & -0.32 & 0.41 \\
\hline $\mathbf{T i}$ & 0.85 & 0.89 & 0.74 & 0.30 & 0.94 & 0.61 & 1 & -0.14 & 0.57 \\
\hline $\mathbf{M n}$ & 0.08 & 0.02 & -0.35 & 0.60 & -0.31 & -0.32 & -0.14 & 1 & 0.25 \\
\hline $\mathbf{F e}$ & 0.54 & 0.48 & 0.50 & 0.38 & 0.56 & 0.41 & 0.57 & 0.25 & 1 \\
\hline
\end{tabular}

\begin{tabular}{|l|l|l|l|l|l|l|l|l|l|}
\hline & PC 1 & PC 2 & PC 3 & PC 4 & PC 5 & PC 6 & PC 7 & PC 8 & PC 9 \\
\hline Eigen & 5.144 & 2.0437 & 0.7322 & 0.3646 & 0.2889 & 0.2024 & 0.1461 & 0.0553 & 0.0227 \\
\hline $\mathbf{d V a r . ~}$ & $56.9 \%$ & $23.8 \%$ & $7.5 \%$ & $3.8 \%$ & $3.2 \%$ & $2.2 \%$ & $1.7 \%$ & $0.6 \%$ & $0.3 \%$ \\
\hline \% Cumul. & $56.9 \%$ & $80.8 \%$ & $88.2 \%$ & $92.0 \%$ & $95.2 \%$ & $97.5 \%$ & $99.1 \%$ & $99.7 \%$ & $100.0 \%$ \\
\hline $\mathbf{M g}$ & 0.39 & -0.18 & -0.19 & -0.31 & -0.33 & 0.13 & 0.72 & -0.20 & 0.08 \\
\hline $\mathbf{A l}$ & $\mathbf{0 . 4 2}$ & -0.16 & -0.34 & -0.10 & 0.01 & -0.18 & -0.15 & 0.78 & 0.05 \\
\hline $\mathbf{S i}$ & 0.36 & 0.20 & 0.06 & $\mathbf{0 . 4 5}$ & 0.33 & $\mathbf{- 0 . 6 0}$ & 0.30 & -0.13 & -0.21 \\
\hline $\mathbf{P}$ & 0.16 & $\mathbf{- 0 . 6 0}$ & -0.15 & 0.18 & $\mathbf{0 . 6 2}$ & 0.36 & -0.03 & -0.19 & 0.06 \\
\hline $\mathbf{K}$ & $\mathbf{0 . 4 2}$ & 0.15 & -0.03 & 0.08 & -0.13 & -0.08 & -0.39 & -0.34 & 0.71 \\
\hline $\mathbf{C a}$ & 0.30 & 0.32 & $\mathbf{0 . 5 6}$ & $\mathbf{- 0 . 5 0}$ & $\mathbf{0 . 4 4}$ & 0.19 & 0.05 & 0.13 & 0.02 \\
\hline $\mathbf{T i}$ & $\mathbf{0 . 4 3}$ & 0.01 & -0.11 & -0.14 & -0.20 & 0.11 & $\mathbf{- 0 . 4 5}$ & -0.31 & $\mathbf{- 0 . 6 6}$ \\
\hline $\mathbf{M n}$ & -0.06 & $\mathbf{- 0 . 6 3}$ & $\mathbf{0 . 4 4}$ & -0.29 & -0.12 & $\mathbf{- 0 . 5 3}$ & -0.12 & -0.09 & 0.02 \\
\hline $\mathbf{F e}$ & 0.25 & -0.16 & $\mathbf{0 . 5 5}$ & $\mathbf{0 . 5 5}$ & -0.36 & 0.34 & 0.05 & 0.25 & -0.03 \\
\hline
\end{tabular}


a) $\mathrm{Sm} 3(\mathrm{PC} 1)^{*}$

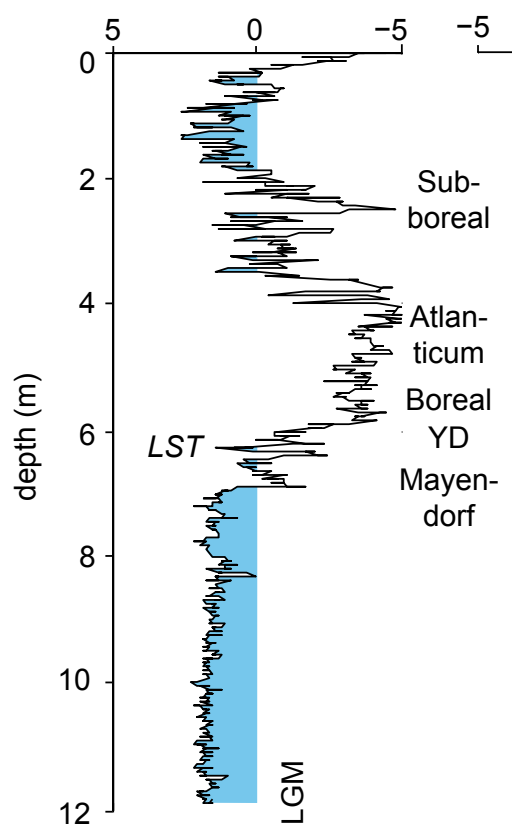

c) $\mathrm{Sm} 3(\mathrm{PC} 2)$

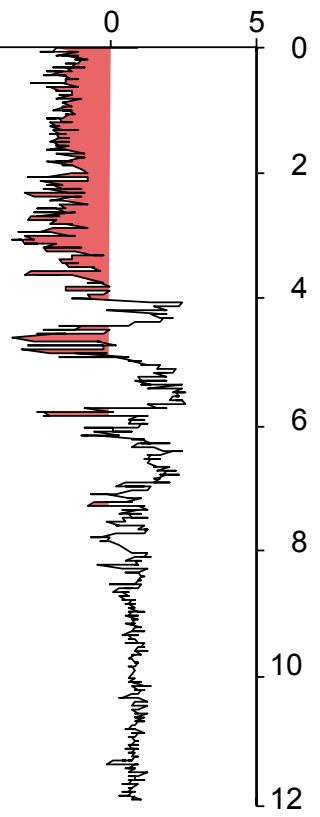

b) De3 (PC 1)

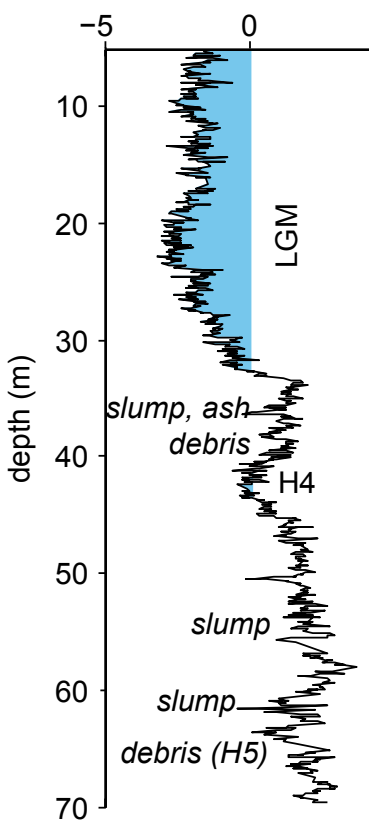

d) De3 (PC 2)

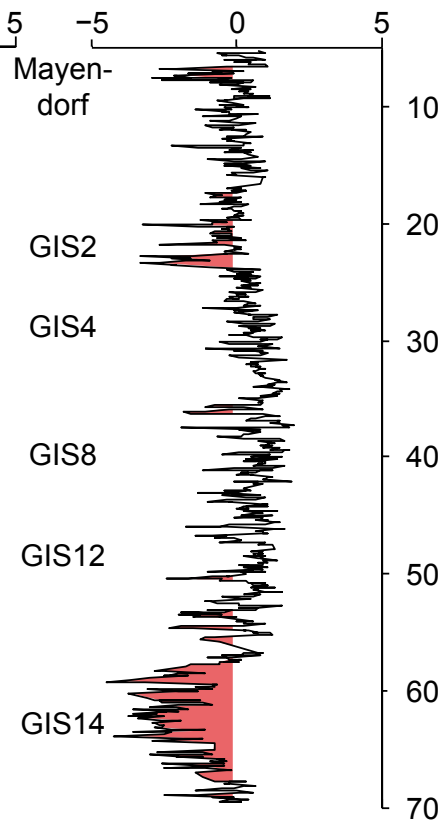

Fig. 6: The first two principal components PC1 and PC2 of each core are shown versus the depth (see tables $3 b, 4 b$ for associated factor loadings). $(a, b)$ PC1 isolates a signal of glacial/aeolian transported sediment (shaded in blue). Aeolian sediments have negative values in the core DE3 and positive ones in the core SM3, respectively ( ${ }^{*}$ For a better visualization the $x$-axis of (b) is inverted). (c,d) PC2 in both cores has in common that they have negative values during warm/humid climate conditions (red color). However, in core SM3 PC2 is characterized by highly redox-sensitive elements (see text). PC2 of core DE3 depends strongly on elements which indicate enhanced chemical weathering.

Abb. 6: Darstellung der beiden ersten Hauptkomponenten (PC1, PC2) gegen die Tiefe des jeweiligen Sedimentkerns (s. Tab. 3b, $4 b$ für dazugehörige Faktorladungen). ( $a, b)$ Äolischer Staub (blaue Füllung) ist im Kern DE3 durch negative PC1-Werte gekennzeichnet, im Kern SM3 durch positive Werte. Zur Verdeutlichung des staubhaltigen Sediments ist die x-Achse der PC1 des Kerns SM3 invers dargestellt. (c, d) PC 2 ist in beiden Kernen unterschiedlich $z$ interpretieren deutet aber auf klimatisch warm/humiden Einfluss hin (rote Färbung). Im Kern SM3 ist PC2 durch redox-sensitive Elemente charakterisiert (s. Text). Im Kern DE3 hängt PC2 stark vom Vorkommen von Elementen ab, die auf erhöhte chemische Verwitterung hindeuten. the redox conditions at the lake bottom with contemporaneous high amount of organic matter. The other factors do not influence aeolian sediment input into the maar lake and account only for a lower percentage of the total variation. In addition, the result of the scree test suggests using the first two factors, only. Consequently, they are of minor interpretative use for this study and not further considered.

\section{Discussion}

For the derivation of paleoclimate or economic conditions from geochemical data two assumptions must hold true (BoyLE, 2001): (1) At any one time the sediment concentration must be proportional to the external element loading and (2) the element concentrations in the sediment must not change after burial. The latter is in discussion especially as regards the role of $\mathrm{Mn}$ and Fe reduction in potential remobilization of trace elements. Boyle (2001) has shown that post depositional alteration and migration is likely, but that this is only significant at extremely low sediment mass accumulation rates and is not likely for high glacial sediment yields. Thus we suggest that the elicitation of a dust signal within maar lake sediments is possible by application of inorganic geochemistry. However, a wider knowledge about the lake's regional setting (location, morphology, presence of inflows, etc) is necessary. Thus, additional information from other proxies is required. This is shown in this study, since all cores show different inorganic geochemical reactions to environmental changes dependent on the regional setting. An example is the stratification of the geogenic elements in the core SM3: All of these elements have a major influence on PC 1, but only the typical "loess-elements" $\mathrm{Si}, \mathrm{Ca}$, and $\mathrm{K}$ have their highest values during glacial conditions.

The results show that there are three different groups of main elements which characterize the sediment. (i) Typical geogenic elements are magnesium (low differentiated volcanic products), potassium (low differentiated volcanic products), titanium and aluminum (lithics, feldspars). In oligotrophic lakes silica, aluminum as well as titanium and potassium represent the clastic input. This is clearly shown for all the cores. The alkali metal $\mathrm{K}$ and the alkaline earth metals $\mathrm{Ca}$ and $\mathrm{Mg}$ are major bedrock constituents. High amounts of these elements represent reduced soil stability and increased erosion. But $\mathrm{Ca}$ and $\mathrm{Mg}$ might have also significant concentrations in authigenic carbonate and skeletal carbonates from invertebrates. The supply of conservative cations $\mathrm{K}$ (and also $\mathrm{Na}$ ) increases with periods of rapid chemical erosion, similar to Ti. These elements are thus enriched during the Holocene and MIS-3 and only minor during MIS-2, when climate was more arid. (ii) Sulphur and phosphorous belong are limnogenic and redox-sensitive elements and thus the precipitation and release processes are complex. The deposition and conservation of the elements $\mathrm{Fe}, \mathrm{Mn}, \mathrm{S}$, and $\mathrm{P}$ is strongly controlled by $\mathrm{pH}$ and redox conditions at the lake bottom (ENGSTROM \& Wright 1984). Since maar lakes usually have anoxic bottom water reduced $\mathrm{Fe}(\mathrm{II})$ precipitates in combination with $\mathrm{S}$, forming the mineral pyrite $\left(\mathrm{FeS}_{2}\right)$. Blue colored vivianite crystals, a ferrous phosphate, occur with increased burial of undecomposed organics. High rates of organic matter deposition 


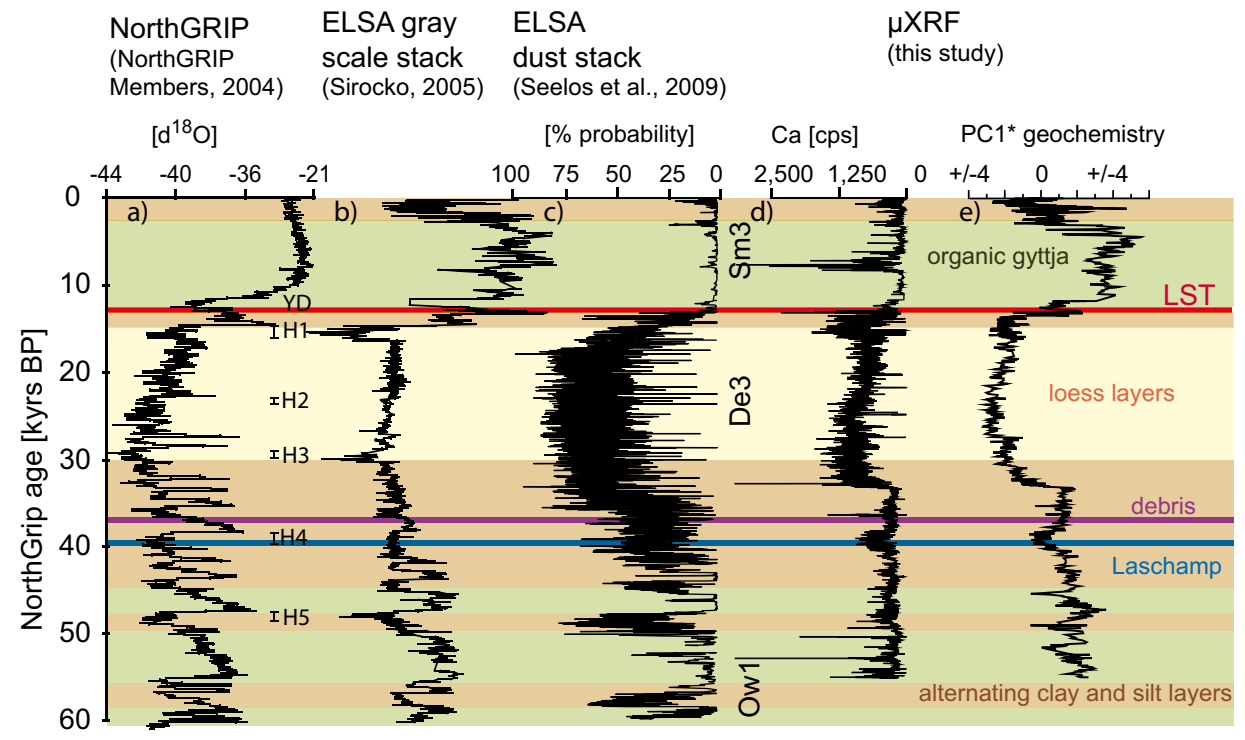

Fig. 7: $\mu X R F$ geochemistry stacks versus the time, (a) NorthGRIP d18O record, (b) the ELSA grayscale stack, (c) the ELSA dust stack, and major litho zones of the last 60 kyrs. $\mathrm{Ca}(\mathrm{d})$ as well as the PCA stack (e) clearly shows the influence of aeolian sediment ( ${ }^{*}$ The SM3 part of the PC 1-stack is inverse; see Fig. 6). Heinrich events after HEMMING (2004).

Abb. 7: $\mu$ XRF-Geochemie-Stacks gegen das Alter: (a) NorthGRIP d18O-Rekord, (b) der ELSA Graustufen-Stack, (c) der ELSA StaubStack und die wichtigsten Lithozonen der Bohrkerne. Die Ca-Werte (d) sowie der PC1Stack (e) zeigen deutlich den Einfluss des äolischen Sediments ( ${ }^{*}$ der SM3-Abschnitt des PC1-Stacks ist invers aufgetragen; siehe Abb. 6). Marine Heinrich-Ereignisse nach HEMMING (2004). occur only during interstadials and interglacials. A second prerequisite for the formation of vivianite is the presence of orthophosphates which are provided by oxic decay. Thus, the occurrence of vivianite in organic rich sediment sections is not a proxy for paleoproductivity (FAGEL et al., 2005). It is an indicator of at least temporary deep circulation at high organic production (VoIGT et al., 2008) and clearly precedes the formation of sulphides in the course of eutrophication (GÄCHTER \& MüLLER, 2003). The presence of Pyrite shows on the other hand the level of aeration of the maar deep water and the occurrence of a monimolimnion, with anoxic water conditions for at least a period of several mixing cycles. Vivianite is found in the cores with a high content of Phosphorous in the DE3 47.7-50 $\mathrm{m}$ and at 70.7-72.7 $\mathrm{m}$ depth, in particular. (iii) The DE3 at third class is a mixed type: Silicon represents minerogenous $\mathrm{SiO}_{2}$ in the clastic fraction as well as amorphous and autogenic $\mathrm{SiO}_{2}$ production, mainly by the silicon shell of diatoms. Calcium is a major constituent of aeolian dust sediments (with provenance of the Devonian or Triassic limestone). Further reasons for high contents of $\mathrm{Ca}$ are the precipitation of $\mathrm{CaCO}_{3}$ caused by detraction of $\mathrm{CO}_{2}$ in the lake water, and biogenic calcium precipitation e.g. in the lime shell of ostracods. Authigenic carbonates were not observed during glacial periods in the core DE3 (DIETRICH \& SeELos 2010) and we suggest this for the other glacial sequences, too. During times of dominant physical weathering $\mathrm{CaCO}_{3}$ grains will be transported to the lake and most of them should quickly reach the lake bottom without significant in-lake chemical reaction (KoINIG et al. 2003). Thus, we suggest that the content of calcium has not changed during settlement at glacial conditions and can be interpreted as a major contributor to the measured dust signal. However, a stack of the elemental stratification of different cores does not seem to be appropriate. The influence of the catchment, different biogeochemical processes in the lake water and bottom makes each maar lake unique, which is reflected in the distribution of the elements.

The focus of this study is on the detection of aeolian sediments by $\mu \mathrm{XRF}$ scanning and PCA. It is shown that the methodology gives reliable results within acceptable error margins but still needs additional information, at least from facies and micro-facies analysis. However, in this study time slices including major climate changes of the last glacial were used to evaluate this approach and are already discussed in early ELSA publications: e.g. the late Weichselian glacial inception and Heinrich events during MIS-3 and 2 (Dietrich \& SeElos 2010), transition I, the Younger Dryas and internal variability of the Holocene (SEELos et al. 2009). A major finding of this study is that the previously used approach demonstrates weaknesses in comparison to high resolution grain size analysis which was used in the mentioned publications by applying the RADIUS technique (SeElos \& Sirocko 2005). For example, the variability of MIS-2 dust sources could only be shown by a combination of mineralogical/geochemical analysis and grain size sorting parameters (DiETRICH \& SEELOS 2010). However, the transition into the glacial climate state is shown within an abrupt trend towards negative values of PC 1 in the core DE3. This signal is highly correlated to the dust detection for the same core published as ELSA dust stack (Fig. 8). The timing of increased dust transport towards the Eifel maar lakes correspond with the global decrease of sea-level 35 kyrs ago (CLARK et al. 2009). An increased east wind frequency for Western Europe was suggested by Dietrich \& SeElos (2010) for the time slice between 33 and 24 kyrs BP. These layers are enriched in aeolian transported carbonate grains in the same sediment core DE3. Since, Ca has a major influence of DE3's PC1, these layers are also reflected in PC 1 (Fig. 7d, e). In addition a severe cold phase which corresponds to the strong Heinrich event H4 (HEMming 2004) is detected by the PCA approach. Another major dust event correlates with H5 (SEELOS et al. 2009) which is reworked by debris in the core DE3 at $65 \mathrm{~m}$ depth, and thus could not be shown by the applied approach.

The younger sediment sequence shows in core SM3 the major climate change from the last glacial to interglacial conditions of the Holocene. Fast environmental changes from the last glacial to the interglacial including the YD are also documented in this core. However, the tephra of the lake Laach eruption shows negative factor scores, too, and is wrongly classified as glacial and aeolian sediment. PC 1 shows a high variability during the Holocene, which is also shown in the lithology and in the grayscale values of the core (Fig. 7). The strong shifts in the aeolian sedi- 
ment proxy in the Holocene (especially the Atlanticum) might also be influenced by changing lake levels during the Holocene. Correlations between the North Atlantic IRD events defined by Bond et al. (1993) and lake level changes in mid-European lakes have been pointed out (MAGNY 2004, 1999; FRIEDRICH et al. 1999), supporting the hypothesis that changes in solar activity have been an important forcing factor of Holocene climate (RENSSEN \& ISARIN 2001). A pronounced $\mathrm{Ca}$ peak corresponds to the strong cold spell of the 8.2-ka-event. This event is only minor correlated with an enhanced dust input in the Eifel area (SEELOS et al. 2009). Here, we suggest that a strong ventilation of the bottom water has led to the precipitation of carbonate minerals. However, PRASAD et al. (2009) suggested temperature to be the primary control on calcite formation. These authors focused on seasonal carbonate precipitates in the sublayers of single warves and found distinct minima of calcite during the 8.2-ka-event which were used as an proxy for cold summer temperatures. In deed, the calcium maximum in SM3 is not continuously on a high level when looking at high resolution $\mu$ XRF scans, but also shows several phases with minimum values (not shown). The major impact of the 160 year 8.2-ka-event on the environment of Central Europe is also shown in many other records e.g. in reduced tree-ring widths from Central German oaks (FrIEDRICH et al. 1999). However, in the Holocene the deposition of aeolian dust plays only a minor role. The elements $\mathrm{Al}, \mathrm{K}, \mathrm{Ti}$ have the highest factor loadings in PC 1 of SM3 and reflect soil destabilization which goes along with erosion and enhanced dust transport. Until the Boreal the environment is characterized by more open landscapes and high physical weathering. These conditions change within the Atlanticum when conditions changed to a warmer and more humid climate. Hence, the soils became more stabilized and the slopes were covered by dense forests. Human activities in the catchment are traced back to ca. 15.5 kyrs BP, long before late glacial warming ca. 14.7 kyrs BP (STREET et al. 2006), but became most pronounced around 3,700 BP (Sirocko, ed. 2009). Deforestation, grazing, and agriculture caused an increase in erosion, physical weathering and thus enhanced deflation of dust. Since then the dust signal in the lake Schalkenmehrener Maar is mainly anthropogenically altered.

\section{Conclusion}

This study investigates whether the detection of aeolian sediment by $\mu \mathrm{XRF}$ scanning of resin impregnated sediment samples with a subsequent PCA approach give reliable results. Changes of aeolian supply over time are suggested in the inorganic geochemistry data, especially in $\mathrm{Ca}, \mathrm{Si}$, and the first new calculated PCA factor (PC 1) which is mainly influenced by $\mathrm{Ca}, \mathrm{Si}$, and $\mathrm{Ti}$. It is demonstrated that this approach works well since for the interpretation further knowledge about the lithology and environmental background is available. The signal of geochemical aeolian proxies might be influenced by autochthonous and allochthounous accumulation changes and without further knowledge and necessary inter proxy comparison the results might be inconsistent or difficult to interpret. Thus, the detection of dust using high resolution grain size analysis is advantageous, because this approach recognizes different transport mechanisms of the sediment and is so far the only method which is able to quantify the content of aeolian dust in sediment. A $\mu \mathrm{XRF}$ is a fast and inexpensive scanning method of the elemental stratification within sediment cores. In addition, the quantification of the main elements via standard less fundamental parameter method gives significant results in comparison to the reference samples, which are measured by WD-XRF. Thus, a calibration of the $\mu \mathrm{XRF}$ results is reliable, if this evaluation is based on at least a reference sample for each litho zone.

Cores SM3 and DE3 show both fully glacial sediment and warm and wet climate conditions and the major dust deposition events and phases could be detected by $\mu \mathrm{XRF}$ geochemistry. These include the largest Heinrich event $\mathrm{H} 4$ during MIS-3, the onset of dust increase coupled to the growing of the Scandinavian Ice sheet, later on the whole MIS-2 including LGM, the YD as well as enhanced dust supply generated by human activities since the Subboreal. In the applied PCA approach PC 1 discriminates in both lake sediment cores aeolian from non aeolian material. Volcanic ash and tephra is mostly classified as aeolian sediment because of the major influence of geogenic elements ( $\mathrm{Si}, \mathrm{Al}, \mathrm{Ti}, \mathrm{K}$ and mostly $\mathrm{Ca}$ ) to $\mathrm{PC}$ 1. Ca has a major influence on the dust signal in both cores and a combination of $\mathrm{Ca}$ with the grayscale values gives the best signal of aeolian sediment. The occurrence of vivianite coincides with enriched amounts of $\mathrm{P}$ and Fe in organic rich gyttja and is thus suggested as a proxy for low sedimentation rates during interstadial climate conditions. In summary, $\mu \mathrm{XRF}$ scanning of bulk geochemistry has shown to be a sensitive indicator of both changes in the lake and in its (aeolian) catchment, if it is used together with other proxy data such as micro facies or grain size analysis.

\section{Acknowledgements}

The authors thank Erzsébet Horváth for her constructive comments and Manfred Frechen for his comments and great support as an editor. We would like to thank Klaus Schwibus and Günther Ritschel for sample preparation and Saskia Rudert for her great assistance at sample measuring. This work is part of the Stephan Dietrich's Phd thesis and funded by the German Science Foundation (DFG, Si594/21-2).

\section{References}

BGR. 1993. Geological Map of Germany. (ger: Geologische Karte der Bundesrepublik Deutschland). scale 1:1,000,000, Hannover.

Bond, G., W. Broecker, S. Johnsen, J. McManus, L. Labeyrie, J. Jouzel \& G. BonANI. 1993. Correlations between climate records from North Atlantic sediments and Greenland ice. Nature 365: 143-147.

Böning, P., E. BARD \& J. Rose. 2007. Toward direct, micron-scale XRF elemental maps and quantitative profiles of wet marine sediments. Geochemistry, Geophysics, Geosystems. 8: Q05004.

BoyLE, J. F. 2000. Rapid elemental analysis of sediment samples by isotope source XRF. Journal of Paleolimnology 23: 213-221.

Boyle, J. F. 2001. Inorganic geochemical methods in palaeolimnology. In: W. M. Last, J. P. Smol \& H. J. B. Birks (Eds.). Tracking Environmental Change Using Lake Sediments: Physical and Geochemical Methods. Vol. 2, pp. 83-141. Springer.

Brauer, A., G. H. Haug, P. Dulski, D. M. Sigman \& J. F.W. Negendank. 2008. An abrupt wind shift in western Europe at the onset of the Younger Dryas cold period. Nature Geoscience 1: 520-523.

Büchel, G. 1994. Vulkanologische Karte West- und Hocheifel. Landesvermessungsamt Rheinland-Pfalz. 
Clark, P. U., A. S. Dyke, J. D. Shakun, A. E. Carlson, J. Cllark, B, Wohlfarth, J. X. Mitrovica, S. W. Hostetler \& A. M. McCABe. 2009 The Last Glacial Maximum. Science 325: 710-714.

Dietrich, S. \& K. Seelos. 2010. The reconstruction of easterly wind directions for the Eifel region (Central Europe) during the period 40.3-12.9 ka BP. Climate of the Past 6: 145-154.

Dietrich, S. \& F. Sirocko. 2009. Korngrößenanalyse und Sedimentgeochemie als Grundlage der Klima- und Wetterrekonstruktion. In F. Sirocko (Ed.). Wetter, Klima, Menschheitsentwicklung. Von der Eis-zeit bis ins 21. Jahrhundert, pp. 26-32. Wissenschaftliche Buchgesellschaft, Darmstadt.

Engstrom, D. R. \& H. E. Wright JR. 1984. Chemical stratigraphy of lake sediments as a record of environmental change. In E. Y. Haworth \& J W. G. Lund (Eds.). Lake sediments and environmental history. Leicester University Press.

Fagel, N., L. Y. Alleman, L. Granina, F. Hatert, E. Thamo-Bozso, R. Cloots $\&$ L. ANDRE. 2005. Vivianite formation and distribution in Lake Baikal sediments. Progress towards reconstructing past climate in Central Eurasia, with special emphasis on Lake Baikal. Global and Planetary Change 46: 315-336.

Francus, P., H. Lamb, T. Nakakawa, M. Marshall, E. T. Brown d Suigetsu 2006 Project Members. 2009. The potential of high-resolution X-ray fluorescence core scanning: Applications in paleolimnology. A new generation of XRF core scanners allows rapid, non-destructive acquisition of high-resolution geochemical and X-radiographic data from lacustrine sediment cores, facilitating new approaches to many applications in paleolimnology, including pollution detection, varve counting\& estimation of past ecosystem productivity. PAGES news 17: 93-95.

Friedrich, M., B. Kromer, M. Spurk, J. Hofmann \& K. Felix Kaiser. 1999. Paleo-environment and radiocarbon calibration as derived from Lateglacial/Early Holocene tree-ring chronologies. Quaternary International 61: 27-39.

Gächter, R. \& B. Müller. 2003. Why the Phosphorus Retention of Lakes Does Not Necessarily Depend on the Oxygen Supply to Their Sediment Surface. Limnology and Oceanography, 48(2), 929-933, http://www.jstor.org/stable/3096591.

GovindARAJU, K. 1989. 1989 compilation of working values and sample description for 272 geostandards. Geostandards and Geoanalytical Research 13: 1-113.

Hemming, S. R. 2004. Heinrich events: Massive late Pleistocene detritus layers of the North Atlantic and their global climate imprint. Reviews of Geophysics, 42(RG1005), 1--43, http://dx.doi. org/10.1029/2003RG000128.

Kido, Y., T. Koshikawa \& R. TADA. 2006. Rapid and quantitative major element analysis method for wet fine-grained sediments using an XRF microscanner. Marine Geology 229: 209-225.

Koinig, K. A., W. Shotyк, A. F. Lotter, C. Ohlendorf \& M. Sturm. 2003 9000 years of geochemical evolution of lithogenic major and trace elements in the sediment of an alpine lake - the role of climate, vegetation \& land-use history. Journal of Paleolimnology 30: 307-320.

MAGNY, M. 1999. Lake-level fluctuations in the Jura and french subalpine ranges associated with ice-rafting events in the north atlantic and variations in the polar atmospheric circulation. Quaternaire 10: 61-64.

MagnY, M. 2004. Holocene climate variability as reflected by mid-European lake-level fluctuations and its probable impact on prehistoric human settlements. The record of Human /Climate interaction in Lake Sediments. Quaternary International 113: 65-79.

Melles, M., J. Brigham-Grette, O. Glushkova, P. Minyuk, N. NowacZYK \& H.-W. HubBerten. 2007. Sedimentary geochemistry of core PG1351 from Lake El'gygytgyn - a sensitive record of climate variability in the East Siberian Arctic during the past three glacial-interglacial cycles. Journal of Paleolimnology 37: 89-104.

Neff, J. C., A. P. Ballantyne, G. L. Farmer, N. M. Mahowald, J. L. Conroy, C. C. Landry, J. T. Overpeck, T. H. Painter, C. R. LaWRENCE \& R. L. REYNOLDS. 2008. Increasing aeolian dust deposition in the western United States linked to human activity. Nature Geosciences 1: 189-195.

Pfahl, S., F. Sirocko, K. Seelos, S. Dietrich, A. Walter \& H. Wernli. 2009. A new windstorm proxy from lake sediments - a comparison of geological and meteorological data from western Germany for the period 1965-2001. Journal of Geophysical Research, 114(D18106), 1-13, doi:10.1029/2008JD011643.
Prasad, S., A. Witt, U. Kienel, P. Dulski, E. Bauer \& G. Yancheva (2009) The 8.2 ka event: Evidence for seasonal differences and the rate of climate change in western Europe. Global and Planetary Change 67 (3-4), 218-226.]

RENSSEN, H. \& R. F.B. IsARIN. 2001. The two major warming phases of the last deglaciation at $\sim 14.7$ and $\sim 11.5 \mathrm{ka}$ cal BP in Europe: climate reconstructions and AGCM experiments. Global and Planetary Change 30: $117-153$

Röhl, U. \& L. J. Aвrams. 2000. High-resolution, downhole and non-destructive core measurements from sites 999 and 1001 in the Caribbean Sea: application to the late Paleocene thermal maximum. In R. M. Leckie, H. Sigurdsson, G. D. Acton and G. Draper (Eds.). Proceedings of the. Ocean Drilling Program. Vol. 165, pp. 191-203, College Station, TX.

Rothwell, R. G. (Ed.). 2006. New Techniques in Sediments Core Analysis - New techniques in sediment core analysis. Vol. 267. Geological Society, London.

SeELos, K. \& F. Sirocko. 2005. RADIUS - rapid particle analysis of digital images by ultra-high-resolution scanning of thin sections. Sedimentology: Vol. 52, No. 3 (2005),669-681.

Seelos, K., F. Sirockoひ S. Dietrich. 2009. A continuous high resolution dust record for the reconstruction of wind systems in Central Europe (Eifel, Western Germany) over the last 133 ka. Geophysical Research Letters, 36(L20712), 1-6, doi:10.1029/2009GL039716.

Sirocko, F., K. Seelos, K. Schaber, B. Rein, F. Dreher, M. Diehl, R. Lehne, K. Jager, M. KrbetscheK \& D. Degering. 2005. A late Eemian aridity pulse in central Europe during the last glacial inception. $\mathrm{Na}$ ture 436: 833-836.

Sirocko, F. (Ed.). 2009. Wetter, Klima, Menschheitsentwicklung. Von der Eiszeit bis ins 21. Jahrhundert. Wissenschaftliche Buchgesellschaft, Darmstadt.

Sorrel, P., H. Oberhänsli, N. Boroffka, D. Nourgaliev, P. Dulski d U. RoHL. 2007. Control of wind strength and frequency in the Aral Sea basin during the late Holocene. Reconstructing past environments from remnants of human occupation and sedimentary archives in western Eurasia. Quaternary Research 67: 371-382.

StraKA, H. (1975). Die spätquartäre Vegetationsgeschichte der Vulkaneifel. Beiträge zur Landespflege in Rheinlandand-Pfalz 3, 1-163.

Street, M., F. Gelnhausen, S. Grimm, F. Moseler, L. Niven, E. Turner, S. Wenzel \& O. JöRIS. 2006. L'occupation du basin de Neuwied (Rhénanie centrale, Allemagne) par les Magdaléniens et les groupes à Federmesser (aziliens). Bulletin de la Société préhistorique française 103: 753-780.

Sun, D., J. Bloemendal, D. K. Rea, J. Vandenberghe, F. Jiang, Z. An ひ R. Su. 2002. Grain-size distribution function of polymodal sediments in hydraulic and aaeolian environments \& numerical partitioning of the sedimentary components. Sedimentary Geology 152: 263-277.

Svensson, A., K. K. Andersen, M. Bigler, H. B. Clausen, D. Dahl-Jensen, S. M. Davies, S. J. Johnsen, R. Muscheler, F. Parrenin, S. O. RASMUSSEN \& others. 2008. A 60000 year Greenland stratigraphic ice core chronology. Climate of the Past 4: 47-57.

VAN DEN BogAARD, P. 1995. 40Ar/39Ar ages of sanidine phenocrysts from Laacher See Tephra (12,900 yr BP): Chronostratigraphic and petrological significance. Earth and Planetary Science Letters 133: 163-174.

Voigt, R., E. GrÜGER, J. BAIER, \& D. MEISCHNER. 2008., Seasonal variability of Holocene climate: a palaeolimnological study on varved sediments in Lake Jues (Harz Mountains, Germany), Journal of Paleolimnology, 40(4), 1021-1052, http://dx.doi.org/10.1007/s10933-008-9213-7.

Weltje, G. J. \& R. TJallingiI. 2008. Calibration of XRF core scanners for quantitative geochemical logging of sediment cores: Theory and application. Earth and Planetary Science Letters 274: 423-438.

Wörner, G. \& H. U. Schmincke. 1984. Petrogenesis of the Zoned Laacher See Tephra. Journal of Petrology 25: 836-851.

Yancheva, G., N. R. Nowaczyk, J. Mingram, P. Dulski, G. Schettler, J. F.W. Negendank, J. Liu, D. M. Sigman, L. C. Peterson \& G. H. HAUG. 2007. Influence of the intertropical convergence zone on the East Asian monsoon. Nature 445: 74-77.

Zolitschka, B. 1998. A 14,000 year sediment yield record from western Germany based on annually laminated lake sediments. Geomorphology 22: 1-17.

Zolitschka, B., A. Brauer, J. F.W. Negendank, H. Stockhausen \& A. LANG. 2000. Annually dated late Weichselian continental paleoclimate record from the Eifel, Germany. Geology 28: 783-786. 